\title{
A Murine Niemann-Pick C1 I1061T Knock-In Model Recapitulates the Pathological Features of the Most Prevalent Human Disease Allele
}

\author{
Maria Praggastis, ${ }^{1}$ Brett Tortelli, ${ }^{1}$ Jessie Zhang, ${ }^{1}$ Hideji Fujiwara, ${ }^{1}$ Rohini Sidhu, ${ }^{1}$ Anita Chacko, ${ }^{1}$ Zhouji Chen, ${ }^{1}$ \\ (1) Chan Chung, ${ }^{2}$ Andrew P. Lieberman, ${ }^{2}$ Jakub Sikora, ${ }^{3}$ Cristin Davidson, ${ }^{3}$ Steven U. Walkley, ${ }^{3}$ Nina H. Pipalia, ${ }^{4}$ \\ Frederick R. Maxfield, ${ }^{4}$ Jean E. Schaffer, ${ }^{1}$ and Daniel S. Ory ${ }^{1}$ \\ ${ }^{1}$ Diabetic Cardiovascular Disease Center and Department of Medicine, Washington University School of Medicine, St. Louis, Missouri 63110, ${ }^{2}$ Department \\ of Pathology, University of Michigan, Ann Arbor, Michigan 48109, ${ }^{3}$ Dominick P. Purpura Department of Neuroscience, Rose F. Kennedy Intellectual and \\ Developmental Disabilities Research Center, Albert Einstein College of Medicine, Bronx, New York 10461, and ${ }^{4}$ Department of Biochemistry, Weill Cornell \\ Medical College, New York, New York 10065
}

\begin{abstract}
Niemann-Pick Type C1 (NPC1) disease is a rare neurovisceral, cholesterol-sphingolipid lysosomal storage disorder characterized by ataxia, motor impairment, progressive intellectual decline, and dementia. The most prevalent mutation, NPC1 ${ }^{11061 \mathrm{~T}}$, encodes a misfolded protein with a reduced half-life caused by ER-associated degradation. Therapies directed at stabilization of the mutant NPC1 protein reduce cholesterol storage in fibroblasts but have not been tested in vivo because of lack of a suitable animal model. Whereas the prominent features of human NPC1 disease are replicated in the null $\mathrm{Npcl}^{-1-}$ mouse, this model is not amenable to examining proteostatic therapies. The objective of the present study was to develop an NPC1 I1061T knock-in mouse in which to test proteostatic therapies. Compared with the $\mathrm{Npcl}^{-l-}$ mouse, this $N p c 1^{\text {tm(IIO6IT)Dso }}$ model displays a less severe, delayed form of NPC1 disease with respect to weight loss, decreased motor coordination, Purkinje cell death, lipid storage, and premature death. The murine NPC1 ${ }^{\mathrm{I} 1061 \mathrm{~T}}$ protein has a reduced half-life in vivo, consistent with protein misfolding and rapid ER-associated degradation, and can be stabilized by histone deacetylase inhibition. This novel mouse model faithfully recapitulates human NPC1 disease and provides a powerful tool for preclinical evaluation of therapies targeting NPC1 protein variants with compromised stability.
\end{abstract}

Key words: cholesterol; lysosomal storage; neurodegeneration; Niemann-Pick C; NPC1; protein misfolding

\section{Introduction}

Niemann-Pick type C (NPC) disease is a fatal neurodegenerative disease caused by a defect in egress of cholesterol and sphingolipids out of lysosomes, which results in a broad array of neurovisceral pathological changes including Purkinje cell death in the cerebellum. Ninety-five percent of NPC disease results from mutations in the NPC1 gene, whereas the remaining 5\% is attributed

Received Oct. 8, 2014; revised March 2, 2015; accepted April 1, 2015.

Author contributions: M.P., J.E.S., and D.S.O. designed research;M.P., B.T., J.Z., H.F., R.S., A.C., Z.C., C.C., J.S., C.D., and N.H.P. performed research; A.P.L. and D.S.O. contributed unpublished reagents/analytic tools; M.P., B.T., J.Z. H.F., R.S., J.S., C.D., S.U.W., N.H.P., F.R.M., J.E.S., and D.S.O. analyzed data; M.P., J.S., C.D., S.U.W., F.R.M., J.E.S., and D.S.O. wrote the paper.

This work was supported by grants from the Hide \& Seek Foundation (D.S.O.), Dana's Angels Research Trust (D.S.O., C.D., and S.U.W.), and the Ara Parseghian Medical Research Foundation (F.R.M.) and by NIH Grants R01 NS081985 (D.S.0. and J.E.S.), R37 DK27083 (F.R.M.), R01 NS063967 (A.P.L.), R01 NS053677 (S.U.W.), R01 HD045561 (S.U.W.), and P30 HD071593 (S.U.W.), and F05 NS074790 (J.S.). This work was performed in the Metabolomics Facility at Washington University (NIH Grant P30 DK020579) and was supported in part by the Hope Center Transgenic Vectors Core at Washington University School of Medicine. We are grateful to Renate Lewis for assistance with generation of the knock-in mouse line. The LAMP1 antibody 1D4B was obtained from the Developmental Studies Hybridoma Bank, created by the NICHD of the NIH, and maintained at The University of lowa.

The authors declare no competing financial interests.

Correspondence should be addressed to Dr. Daniel S. Ory, Diabetic Cardiovascular Disease Center, Washington University School of Medicine, Box 8086, 660 S. Euclid Avenue, St. Louis, M0 63110. E-mail: dory@wustl.edu.

DOI:10.1523/JNEUROSCI.4173-14.2015

Copyright $\odot 2015$ the authors $\quad 0270-6474 / 15 / 358091-16 \$ 15.00 / 0$ to defects in NPC2 (Millat et al., 1999; Ory, 2000; Walkley and Suzuki, 2004). NPC patients typically present in early childhood with progressive impairment of motor and intellectual function and usually die within the first two decades of life (Vanier, 2010). There are currently no Food and Drug Administration-approved therapies for this disorder.

The NPC1 gene encodes a polytopic, highly glycosylated transmembrane protein that localizes to the limiting membrane of the late endosome/lysosome (Carstea et al., 1997; Davies and Ioannou, 2000). NPC1 protein binds unesterified cholesterol within the lysosome, interacting with NPC2 and facilitating cholesterol egress (Millard et al., 2000; Infante et al., 2008; Kwon et al., 2009). Cells harboring mutations in NPC1 sequester unesterified cholesterol in lysosomes and exhibit impairment of mobilization and re-esterification of LDL cholesterol (Neufeld et al., 1999; Millard et al., 2000; Wojtanik and Liscum, 2003).

The most common NPC1 mutation, I1061T $\left(\mathrm{NPC1}^{\mathrm{I1061T}}\right)$, represents $15-20 \%$ of all human disease alleles (Millat et al., 1999; Davies and Ioannou, 2000; Park et al., 2003). This mutation results in misfolded NPC1 protein, which is targeted for ERassociated degradation (Gelsthorpe et al., 2008). Overexpression of NPC1 $1^{\text {I1061T }}$ protein results in lysosomal localization of mutant protein and complementation of the mutant phenotype, likely 
caused by a small proportion of NPC1 $1^{\mathrm{I} 1061 \mathrm{~T}}$ protein that assumes proper conformation and escapes ER quality control checkpoints (Gelsthorpe et al., 2008). Recently, histone deacetylase (HDAC) inhibitors have been shown to increase synthesis of $\mathrm{NPC1}^{\mathrm{I} 1061 \mathrm{~T}}$ protein and cholesterol egress from lysosomes (Kim et al., 2007; Munkacsi et al., 2011; Pipalia et al., 2011). These findings raise the possibility that small moleculebased proteostatic therapies might stabilize mutant NPC1 proteins and have the potential to provide clinical benefit.

Development of proteostatic therapies for NPC1 disease requires testing candidate therapies in a suitable disease model. Many of the prominent neuropathological features of human NPC disease are modeled in the BALB/c Npc1 ${ }^{\text {nih }}\left(N p c 1^{-/-}\right)$mouse, but this model does not synthesize NPC1 protein and, therefore, is not amenable to proteostatic therapies (Pentchev et al., 1980; Morris et al., 1982; Shio et al., 1982; Higashi et al., 1993; Loftus et al., 1997). An $n p c 1^{p f / p f}$ knock-in mouse that ablates cholesterol binding in the NPC1 N-terminal domain was recently generated, but the P202A/F203A mutations result in complete loss of NPC1 function and do not destabilize the mutant protein (Xie et al., 2011). A second naturally occurring mouse model, $N p c 1^{\text {nmf164}}$, expresses a D1005G amino acid substitution in the NPC1 protein; however, the D1005 residue is not conserved in human protein, and there is no evidence that the mutation affects protein folding or stability (Maue et al., 2012). To address the need for an animal model in which to test proteostatic therapies for NPC1 disease, we generated an $N p c 1^{t m(11061 T) D s o}$ knock-in mouse model (referred to as $N p c 1^{I 1061 T}$ ). This novel model faithfully recapitulates disease caused by the human NPC1 $1^{\text {I1061T }}$ mutation and may prove useful for preclinical evaluation of proteostatic therapies for NPC1 disease.

\section{Materials and Methods}

Generation of $\mathrm{Npcl}^{\text {tm(I1061T)Dso }}$ knock-in mice. The murine Npcl genomic locus was inserted into a mouse 129 bacterial artificial chromosome (BAC) construct (BAC identification number bMQ-398C12). The I1061T mutation, ATA to ACA at amino acid 1061 in exon 21, was introduced via galactokinase (galK)-based recombineering as described previously (Warming et al., 2005). A silent mutation was also introduced at alanine 1058 (GCT to GCC) to engineer an MspI restriction site for genotyping. A loxP site was inserted via recombineering (Lee et al., 2001), within a nonconserved region $\sim 220$ bp upstream of exon 12, eliminating a wild-type (WT) NdeI site. A loxP-frt-pGK-neomycin-frt expression cassette was inserted within a nonconserved region $\sim 800$ bp downstream of exon 20 , serving

A

B

C
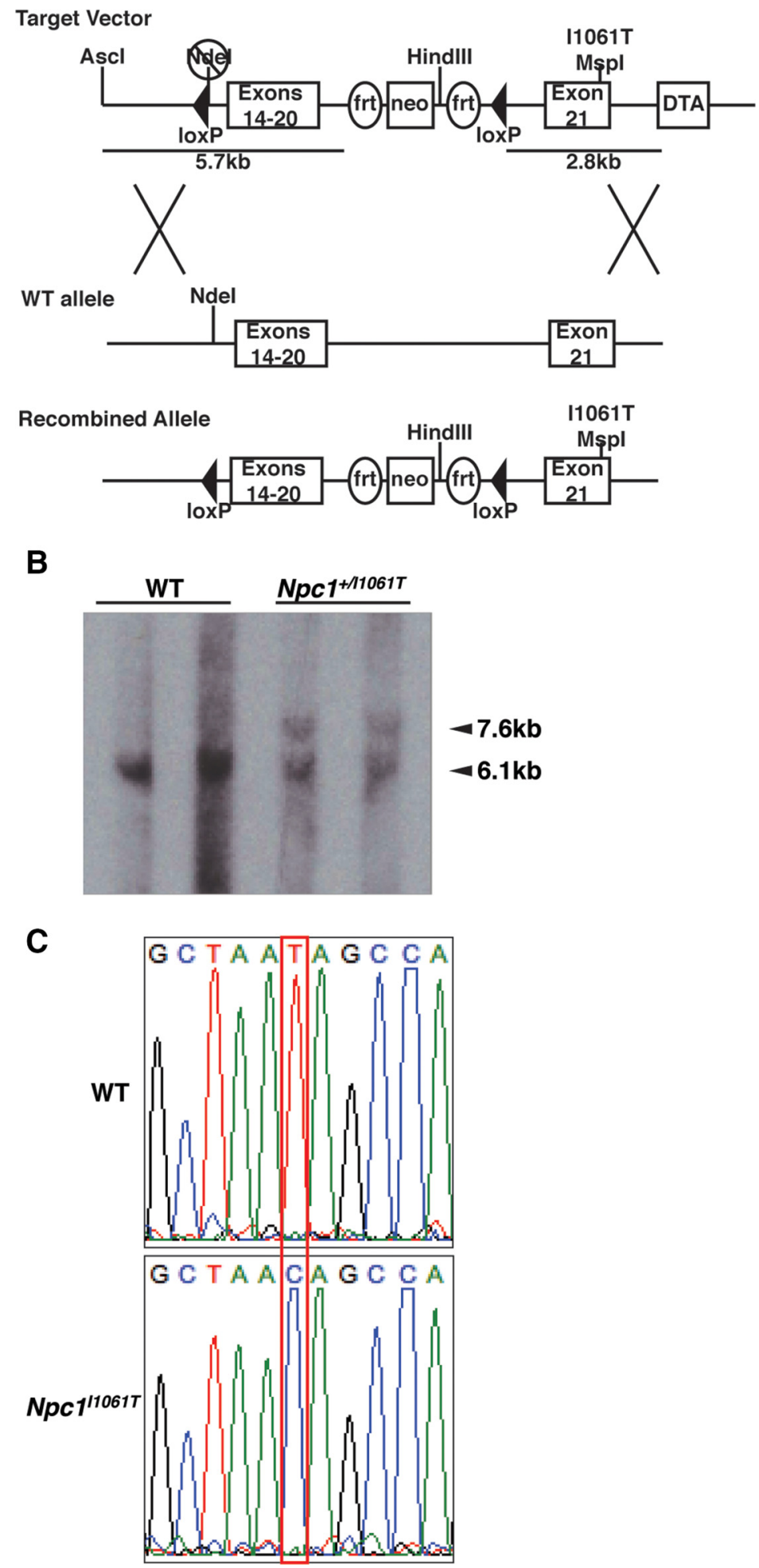

Figure 1. Knock-in strategy for the $N p c 7^{17061 T}$ mouse model. $A$, Diagram of the knock-in targeting vector, the WT NPC1 allele, and the resulting recombined allele. $\boldsymbol{B}$, Restriction digest of genomic DNA, followed by Southern blotting in ES cells. Genomic DNA from WT and $\mathrm{NpC}^{+/ 11061 T}$ mice was digested with Ndel and Hindlll to produce a $6.1 \mathrm{~kb}$ band from the WT allele and a $7.6 \mathrm{~kb}$ band from the knock-in. $C$, Electropherogram of NPC1 CDNA sequence data, showing the ATA-to-ACA mutation at the 1061 amino acid position.

as positive selection in embryonic stem (ES) cells. Conditional deletion of exons 14-20 introduces a frameshift and multiple premature stop codons, providing the option of conditional Npcl knockout for future experiments. The targeting vector was generated from the engineered BAC using gap repair, inserted into a plasmid vector containing a diph- 
theria toxin cassette for negative selection in 129 ES cells (Lee et al., 2001), and linearized for ES cell electroporation with AscI. PCR analysis was performed using an external primer $3^{\prime}$ of the short arm and an internal primer within the neomycin cassette. Southern blot analysis of NdeI or NdeI/HindIII digestion products confirmed homologous recombination in the ES cells. Cells were injected into C57BL/6 blastocysts and implanted in C57BL/6 mothers. Resulting chimeras were then bred with FLPeR C57BL/6 mice (catalog \#003946; The Jackson Laboratory) to excise the neo cassette. Excision was confirmed via PCR and HindIII digestion. These mice were then backcrossed into The Jackson Laboratory C57BL/6 background for five generations. Mice were kept in a controlled animal facility and given standard chow and water ad libitum. Weaning occurred between 3 and 4 weeks. Experimental procedures were approved by the Washington University and University of Michigan Animal Studies Committees and were conducted in accordance with the USDA Animal Welfare Act and the Public Health Service Policy for the Humane Care and Use of Laboratory Animals.

Genotyping. Npc1 $1^{\text {tm(I1061T)Dso }}$ (referred to as $N p c 1^{I 1061 T}$ ) knock-in mice were identified via a PCR-based genotyping method with the following primers: forward, $5^{\prime}$-tgatctgcacacttggaaccgag- $3^{\prime}$; and reverse, $5^{\prime}$ cactgccttgagcagcatctcag- $3^{\prime}$. The WT Npc1 allele produced a $200 \mathrm{bp}$ fragment, whereas the knock-in allele produced a $234 \mathrm{bp}$ fragment. MspI restriction digest also confirmed the presence of the I1061T point mutation.

Functional evaluation of mice. For animal survival and behavioral studies, the groups were balanced between males and females $\left(\mathrm{Npcl}^{-1-}\right.$ mouse studies, four males/four females; $N p c 1^{I 1061 T}$ mouse studies, six males/six females), and the general clinical condition of the mice was monitored daily. Mice were weighed weekly beginning at 4 weeks of age until they died. Death was defined as either being found dead in the cage or by the inability to eat or drink on their own, necessitating euthanasia. Cerebellar function was evaluated weekly by measuring retention time on a rotating drum at $15 \mathrm{rpm}$ (Langmade et al., 2006). For each run, cumulative retention time on the drum was determined for three consecutive attempts (a maximum of $180 \mathrm{~s}$ per attempt). Mice were tested in the morning and in the afternoon, and the rotarod score was determined as the highest cumulative retention time for an individual session.

Real-time quantitative RT-PCR. Mice were killed, and liver and cerebellum were flash-frozen in liquid nitrogen and stored at $-80^{\circ} \mathrm{C}$. RNA was harvested by homogenization in Trizol reagent (Invitrogen) as per the manufacturer's protocol. cDNA libraries were made via the Superscript III First Strand Synthesis System (Invitrogen) with provided oligo dT primers. Real-time quantitative RT-PCR (RT-qPCR) analysis was performed with reported primer sequences (Li et al., 2005; Liu et al., 2010). Relative quantification of gene expression was performed using the comparative threshold $\left(C_{\mathrm{T}}\right)$ method as described previously (Millard et al., 2005). Fold changes in the mRNA expression level were calculated following normalization to 36B4, a ribosomal mRNA.

Protein preparation and Western blot analysis. Protein was harvested from flash-frozen liver and brain tissues as described previously (Newberry et al., 2003). Cultured cells were harvested in RIPA buffer $(10 \mathrm{~mm}$ Tris-Cl, pH 8.0, 1 mm EDTA, 0.5 mm EGTA, 1\% Triton X-100, 0.1\% sodium deoxycholate, $0.1 \%$ SDS, $140 \mathrm{~mm} \mathrm{NaCl}$ ) with Complete Protease Inhibitor Mixture (Roche) and $1 \mathrm{~mm}$ phenylmethylsulfonyl fluoride and incubated on ice for $10 \mathrm{~min}$. Postnuclear supernatant was obtained by centrifuging for $10 \mathrm{~min}$ at $12,000 \times g$ at $4^{\circ} \mathrm{C}$. Protein concentration was quantified using the BCA Protein Assay kit (Pierce). Nonboiled protein samples were resolved by $7.5 \%$ SDS-PAGE under reducing conditions. Proteins were transferred onto polyvinylidene difluoride $(0.45 \mathrm{~mm}$; Millipore) using a semidry electroblotter (Owl Scientific). Western blot analysis was performed using an affinity-purified rabbit anti-human NPC1 antibody at a dilution of 1:2500 (Millard et al., 2000) and rabbit anti-human HSP90 (Enzo/Stressgen) at a dilution of 1:5000. Detection was performed by chemiluminescence using a peroxidase-conjugated donkey anti-rabbit IgG (Jackson ImmunoResearch Laboratories) at 1:5000.

Endoglycosidase treatments. Liver and brain tissues were isolated and protein was harvested as described previously (Newberry et al., 2003).
A
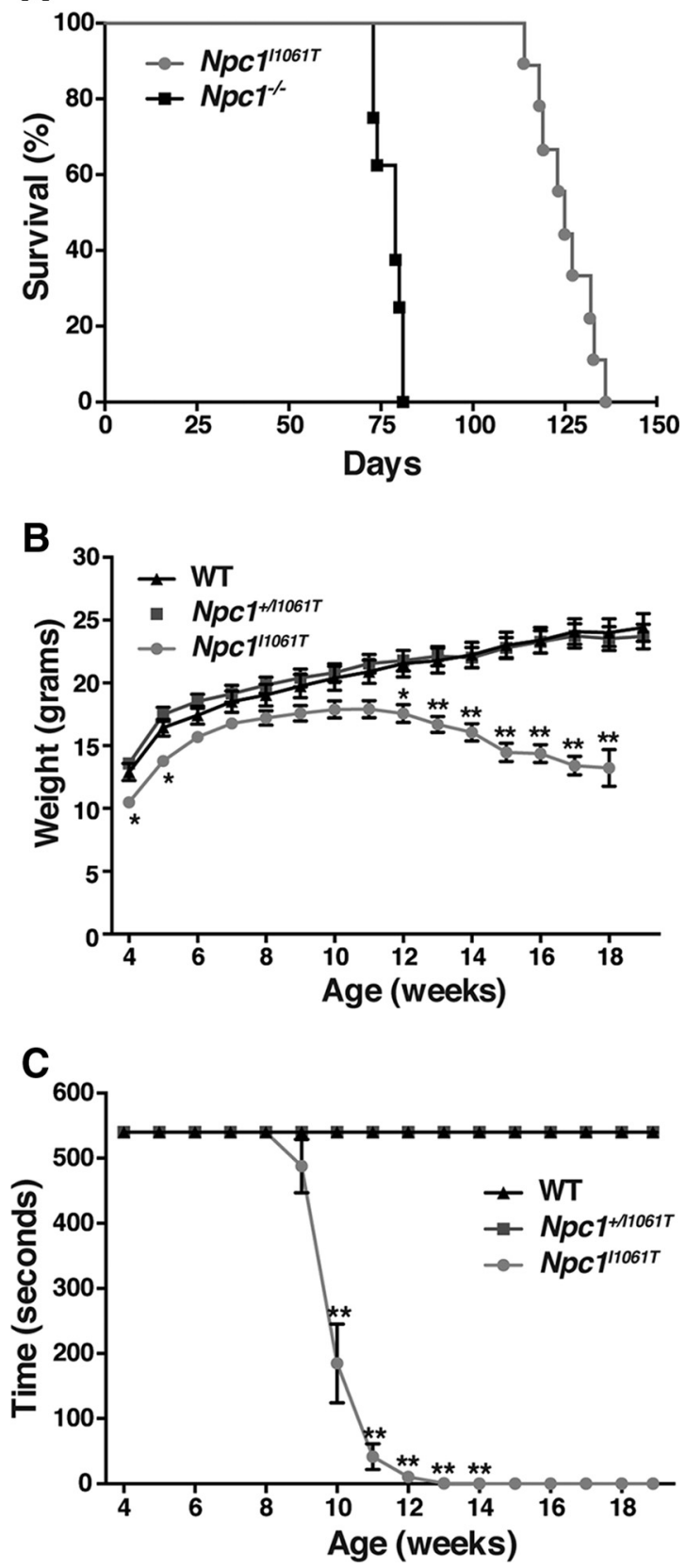

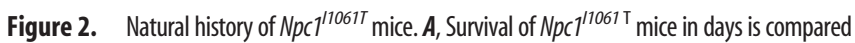
with the NIH Npc1 $1^{-1-}$ model. Npc7 ${ }^{-1-}, n=8 ; \mathrm{Npc}^{17061 T}, n=12 . \mathrm{B}$, Weights of WT, heterozygous $\left(\mathrm{Npc} \mathrm{C}^{+/ 11061 T}\right)$, and homozygous $\left(\mathrm{Npc} \mathrm{1}^{11061 T}\right)$ mice, recorded weekly beginning at week 4. $\mathrm{C}$, Rotarod testing was used to evaluate motor function on a constant $15 \mathrm{rpm}$ rotating drum. Values reported are the sum of the time on the rotarod for 3 consecutive attempts. ${ }^{*} p<0.05 ;{ }^{* *} p<0.001$.

Protein samples were incubated with endoglycosidase $\mathrm{H}$ (New England Biolabs) or PNGaseF (New England Biolabs) for $7 \mathrm{~h}$ at $37^{\circ} \mathrm{C}$ in $5 \mathrm{~mm}$ sodium phosphate with $1 \%$ NP-40.

Hepatocyte isolation and cycloheximide treatment. Mouse hepatocytes were isolated from postnatal day 35 (P35) mice and cultured as described previously (Chen et al., 2000). NPC1 ${ }^{\mathrm{I} 1061 \mathrm{~T}}$ homozygous fibroblasts 59413 were obtained from Dr. John O'Brien (Mayo Clinic, Rochester, $\mathrm{MN}$ ) and cultured as reported previously (Gelsthorpe et al., 2008). At $24 \mathrm{~h}$ after plating, cells were treated with $30 \mu \mathrm{g} / \mathrm{ml}$ cycloheximide (CHX; Sigma) in growth medium for the indicated time periods, lysed, and subjected to Western blot analysis as described above.

Immunohistochemistry of murine tissues. Mouse tissues were collected at indicated time points. Mice were perfused with $0.9 \%$ saline solution, 
A

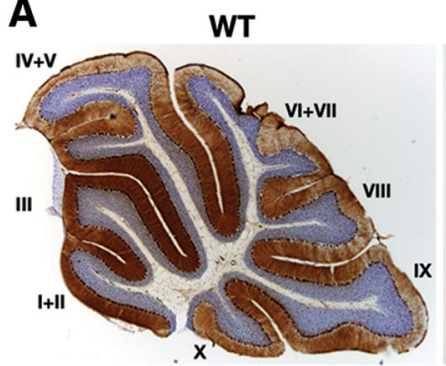

Npc1 $1^{11061 T}$ P63

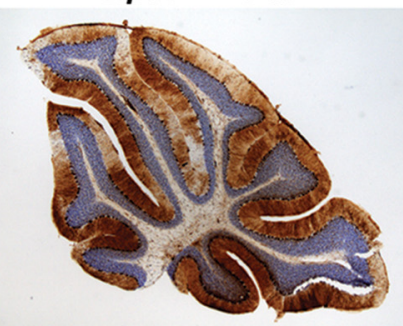

Npc1 ${ }^{11061 T}$ P105

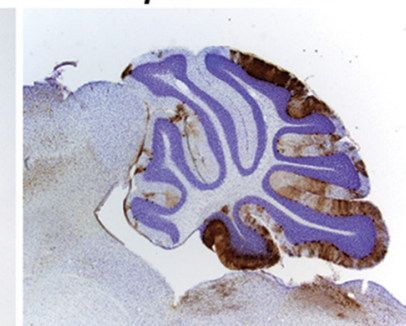

Npc1 1- P63 $^{-1}$

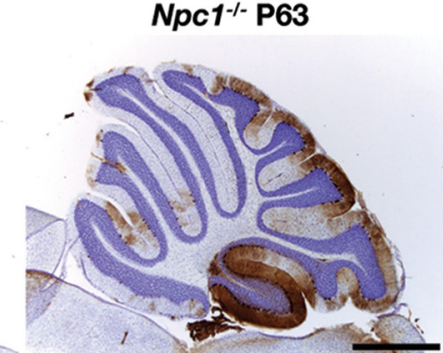

B

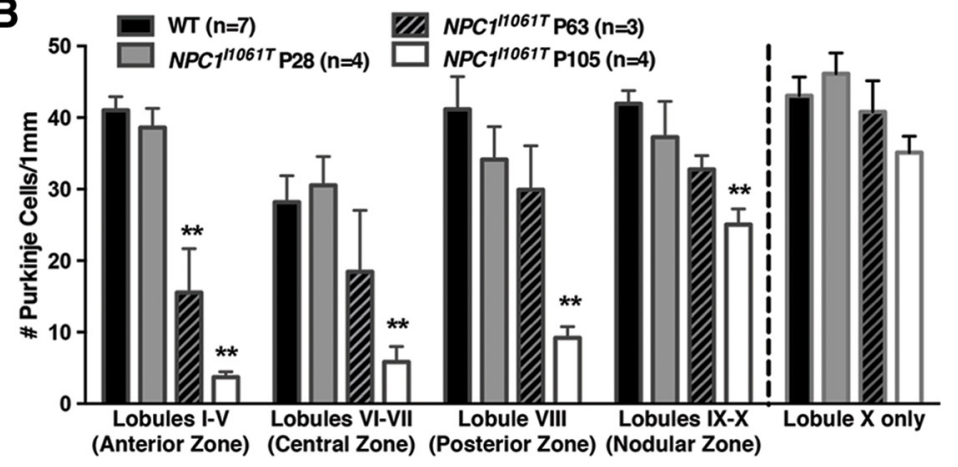

\section{E Npc1 ${ }^{11061 T}$ P63}

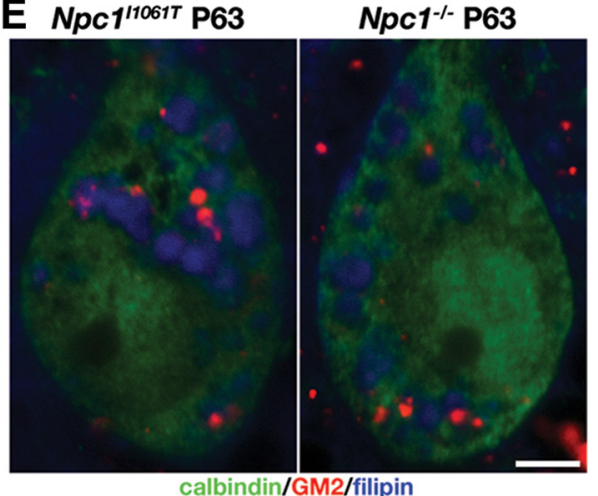

C

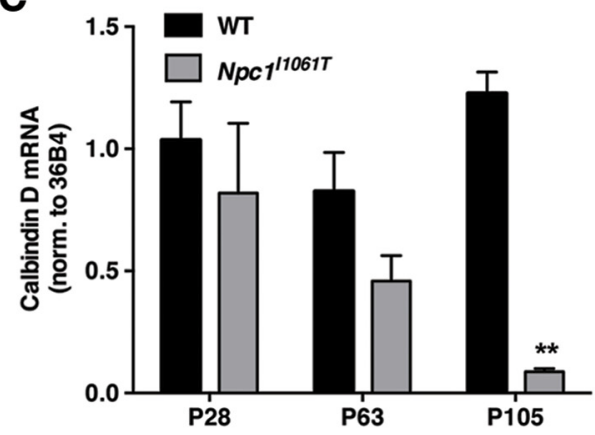

$\mathbf{F}$

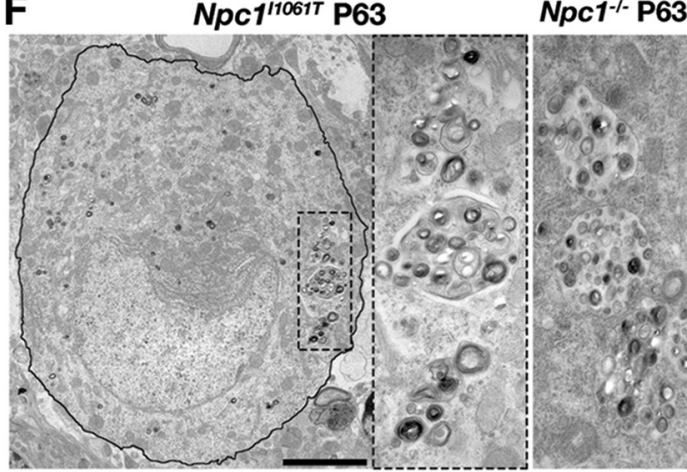

Figure 3. Cerebellar/Purkinje cell neuropathology of $N p c 7^{17061}$ mice. $A$, Temporal progress of patterned Purkinje cell loss (brown, calbindin D; Nissl nuclear counterstain). B, Purkinje cell density evaluated in cerebellar zones [schematically corresponding to (60)].C, RT-qPCR quantification of calbindin D mRNA in the brains ofWT and Npc ${ }^{11061 T}$ mice ages P28, P63, and P105 ( $n=4$ per group).D, Example of regressive changes in a lobule V Purkinje cell (green), reduction and dystrophy of a dendritic tree, and formation of axonal spheroids (arrows), likely affecting both the main axon and axonal collateral. Extensive microglial pathology (purple, (D68) is observed in molecular, Purkinjecell, and granular cell layers. The image is a MIP of a 16.2- $\mu \mathrm{m}$-thick Zstack. E, Storage of cholesterol and GM2 ganglioside is shown in lobuleX Purkinje cells. F, Ultrastructural appearance of polymembranous cytoplasmicstorage bodies in a lobuleXPurkinje cell (cytoplasmicmembrane outlined) of an Npc $7^{17061 T}$ mouse compared with Npc ${ }^{-1-}$ mice (equivalent magnification of lobule X Purkinje cell cytoplasm). ML, Molecular layer; PCL, Purkinje cell layer; GCL, granule cell layer. ${ }^{* *} p<0.001$. Scale bars: $A, 1 \mathrm{~mm} ; \boldsymbol{D}, 50 \mu \mathrm{m} ; \boldsymbol{E}, \boldsymbol{F}, 5 \mu \mathrm{m}$.

and tissue blocks were immediately drop-fixed in $4 \%$ paraformaldehyde overnight at $4^{\circ} \mathrm{C}$. Tissues were then rinsed and stored in $0.1 \mathrm{M}$ phosphate buffer at $4^{\circ} \mathrm{C}$. Tissues were sectioned $(35 \mu \mathrm{m})$ and stained as described previously (McGlynn et al., 2004; Davidson et al., 2009). Primary antibodies $\alpha$-GM2 ganglioside (mouse, in house) and $\alpha$-calbindin (mouse, Sigma) were used at 1:200 and 1:3000, respectively. Biotinylated $\alpha$-mouse IgM and $\alpha$-mouse IgG secondary antibodies (both from Vector Laboratories) were diluted 1:200. Sections were evaluated, and wide-field images were acquired on a Zeiss AxioSkop2 Plus microscope with an AxioCam MRc CCD (AxioVision 4.4 software) using $2.5 \times$ (NA 0.075) or $10 \times$ (NA 0.3) objectives or on an Olympus AX70 microscope with a MagnaFire CCD (MagnaFire version 2.1 software) using a 10× (NA 0.3) objective. Images were processed, and figures were prepared in ImageJ (version 1.48; NIH) and Adobe Photoshop (version CS6). Images were corrected for nonspecific background and, if necessary, stretched to fit the full dynamic eight-bit range.

Immunofluorescence staining of murine tissues. Mouse tissues were harvested and sectioned as described above. Primary antibodies were used at the following dilutions: $\alpha$-GM2 ganglioside (mouse, in house), 1:25; $\alpha$-calbindin (mouse, Sigma), 1:3000; $\alpha$-calbindin (rab- bit, Millipore), 1:800; $\alpha$-NeuN (mouse, Millipore Bioscience Research Reagents), 1:1000; $\alpha$-CD68 (rat, AbD Serotec), 1:1000; $\alpha$-GFAP (mouse, Sigma), 1:3000. Goat secondary antibodies (1:250, all from Invitrogen) targeting the following species/isotypes and conjugated to Alexa Fluor fluorophores (AF) were $\alpha$-mouse IgM AF546, $\alpha$-rat IgG AF488, $\alpha$-mouse IgG AF546, $\alpha$-mouse IgG AF488, and $\alpha$-rabbit IgG AF488. To avoid cross-reactivity with the primary $\alpha$-GM2 ganglioside antibody, goat $\alpha$-mouse IgG AF488 (1:450; Jackson ImmunoResearch Laboratories) was used. Filipin complex from Streptomyces filipinensis (Sigma) was dissolved in DMSO (Sigma) and used at a final concentration of 0.05 $\mathrm{mg} / \mathrm{ml}$. Confocal images were acquired on a Zeiss 510 Duo V2 laserscanning microscope using $20 \times($ NA 0.80 ) or $63 \times$ oil (NA 1.4) objectives and 351, 488, and $543 \mathrm{~nm}$ excitation lasers. Image acquisition conditions (laser intensities, pinhole size, dichroic mirrors, bandpass filters, photomultiplier gains) were kept constant for particular combinations of dyes. Emission wavelength filtering was set to minimize cross talk, and excitation and emission collection was performed sequentially for individual fluorophores. Selected $Z$ stacks are presented as single-plane maximumintensity projections (MIPs). 
A

WT

Npc1 $1^{11061 T}$ P28

Npc1 11061T P63

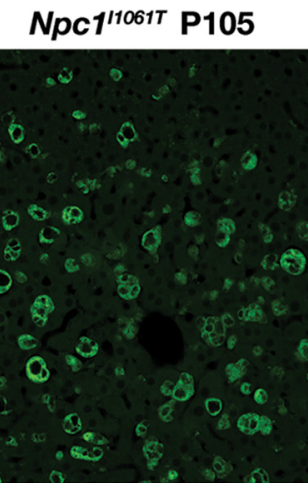

Npc1 $^{-/-}$P63
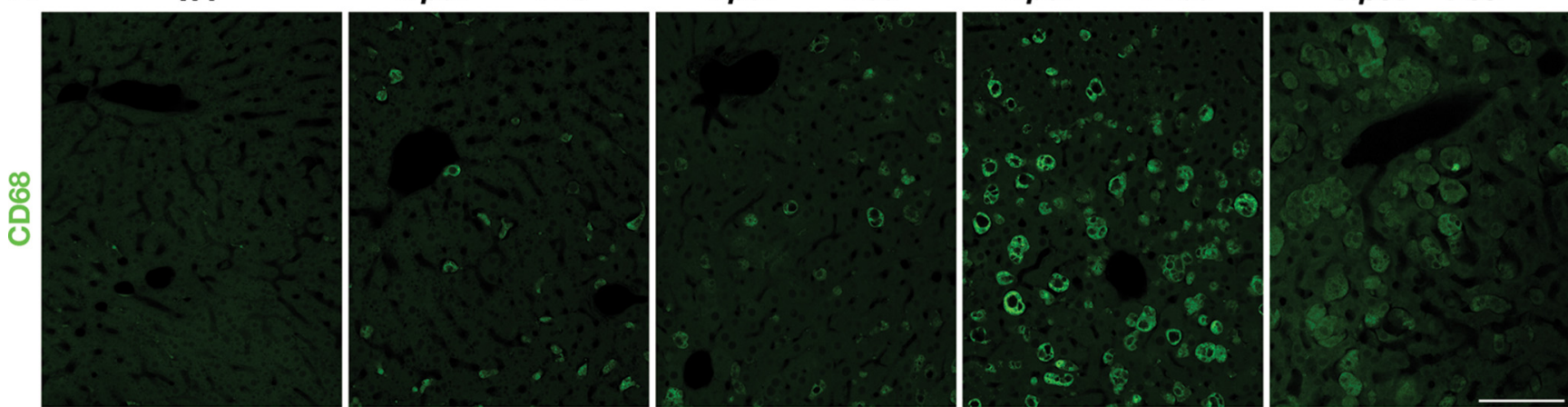

B

WT

Npc1 ${ }^{11061 T}$ P28
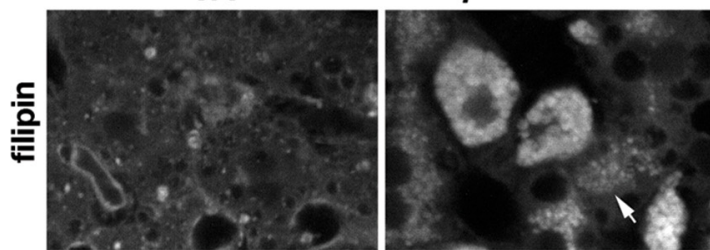

Npc1 $1^{11061 T}$ P63

Npc1/1061T P105

Npc1 $^{-/-}$P63
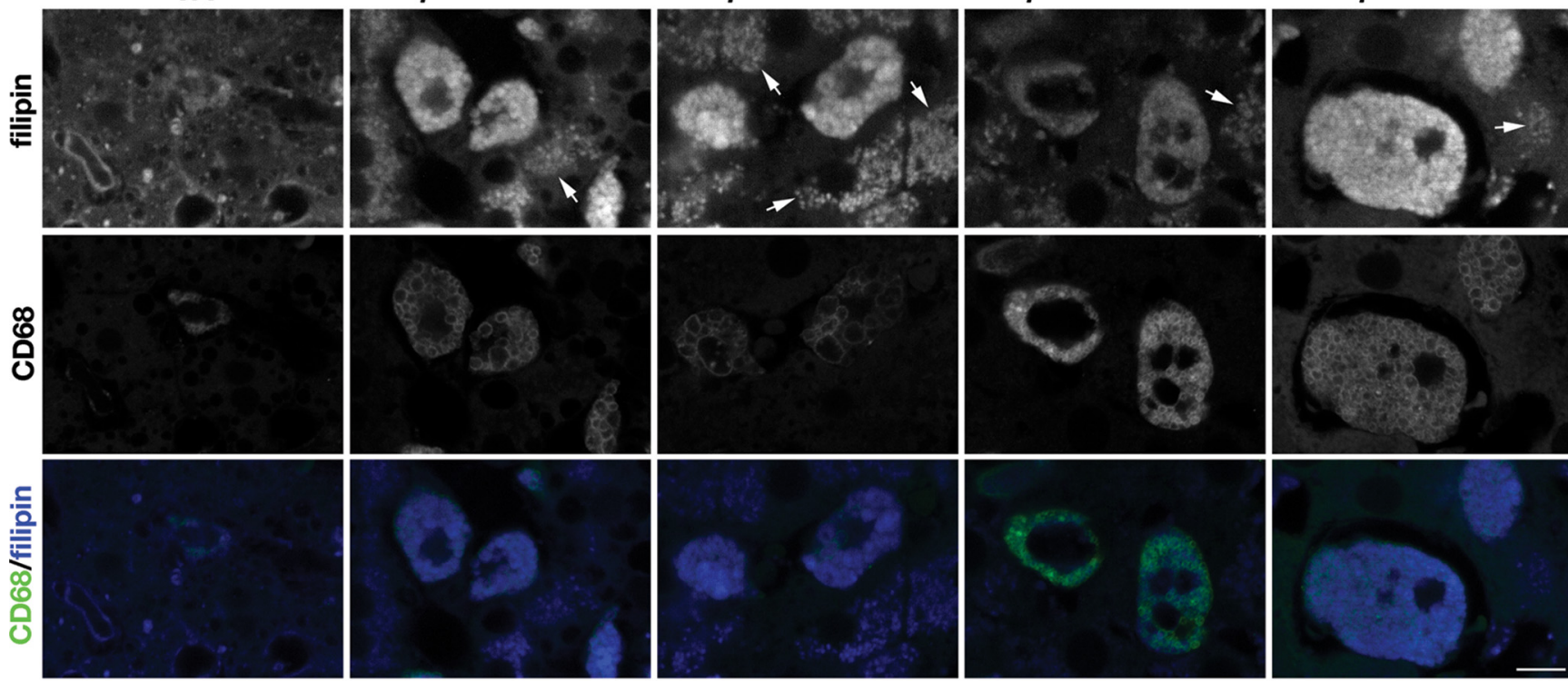

C
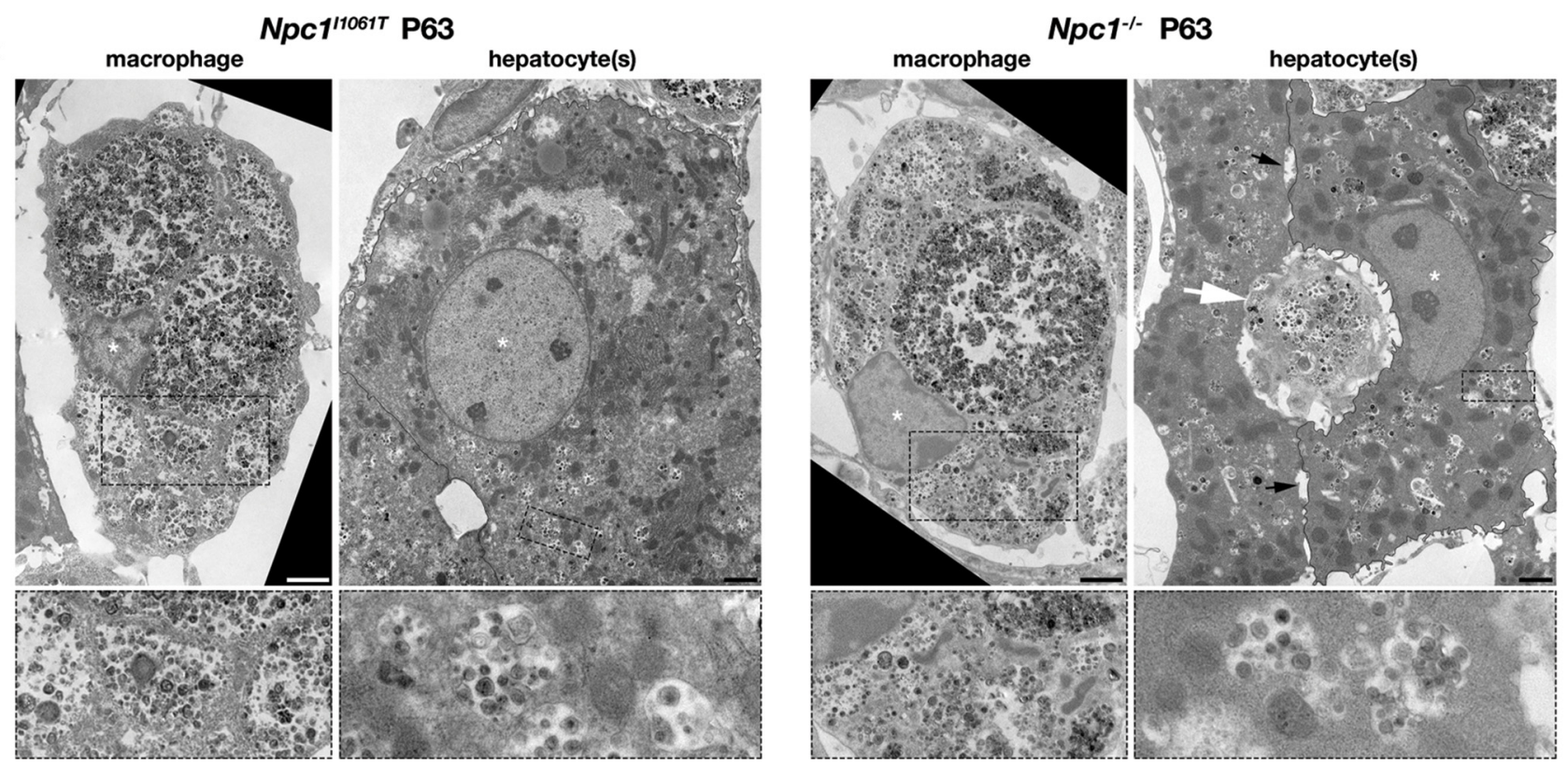

Figure 4. Hepatocyte and macrophage pathology in liver of $\mathrm{Npc} 7^{11061 T}$ mice. $\boldsymbol{A}$, Liver macrophages (green, $(\mathrm{D} 68+$ ) increase in number and exhibit a progressive foamy transformation in $\mathrm{Npc} \mathrm{T}^{17061 T}$ mice. B, Cholesterol accumulation (as visualized by filipin labeling) in both liver macrophages and hepatocytes (arrows). C, Ultrastructural pathology in liver macrophages and hepatocytes at P63. Detailed views of polymembranous storage bodies are shown in the insets outlined by the dashed lines. Asterisks indicate nuclei; black arrows indicate biliary canaliculi, and the white arrow indicates macrophage. Scale bars: $\boldsymbol{A}, 100 \mu \mathrm{m} ; \boldsymbol{B}, 10 \mu \mathrm{m} ; \boldsymbol{C}, 2 \mu \mathrm{m}$. 
A

WT

Npc1 $^{11061 T}$ P28
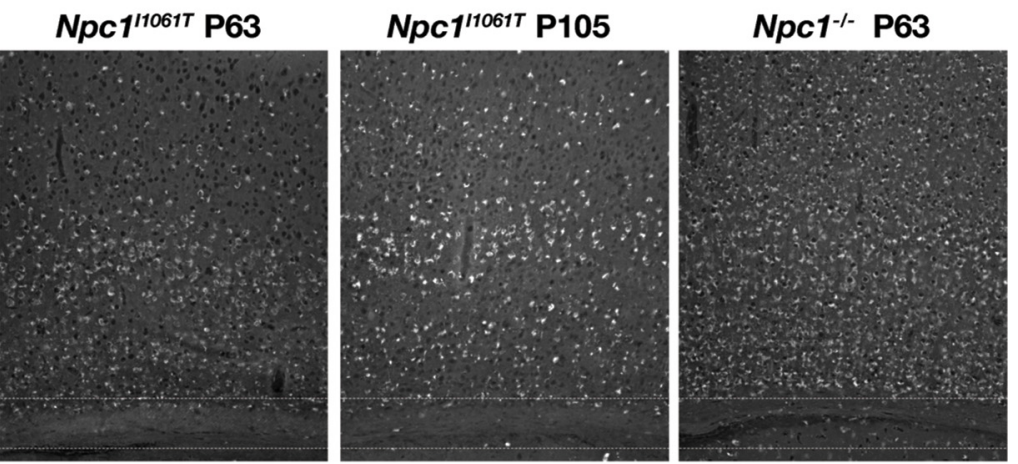

Npc1 $^{-/-}$P63
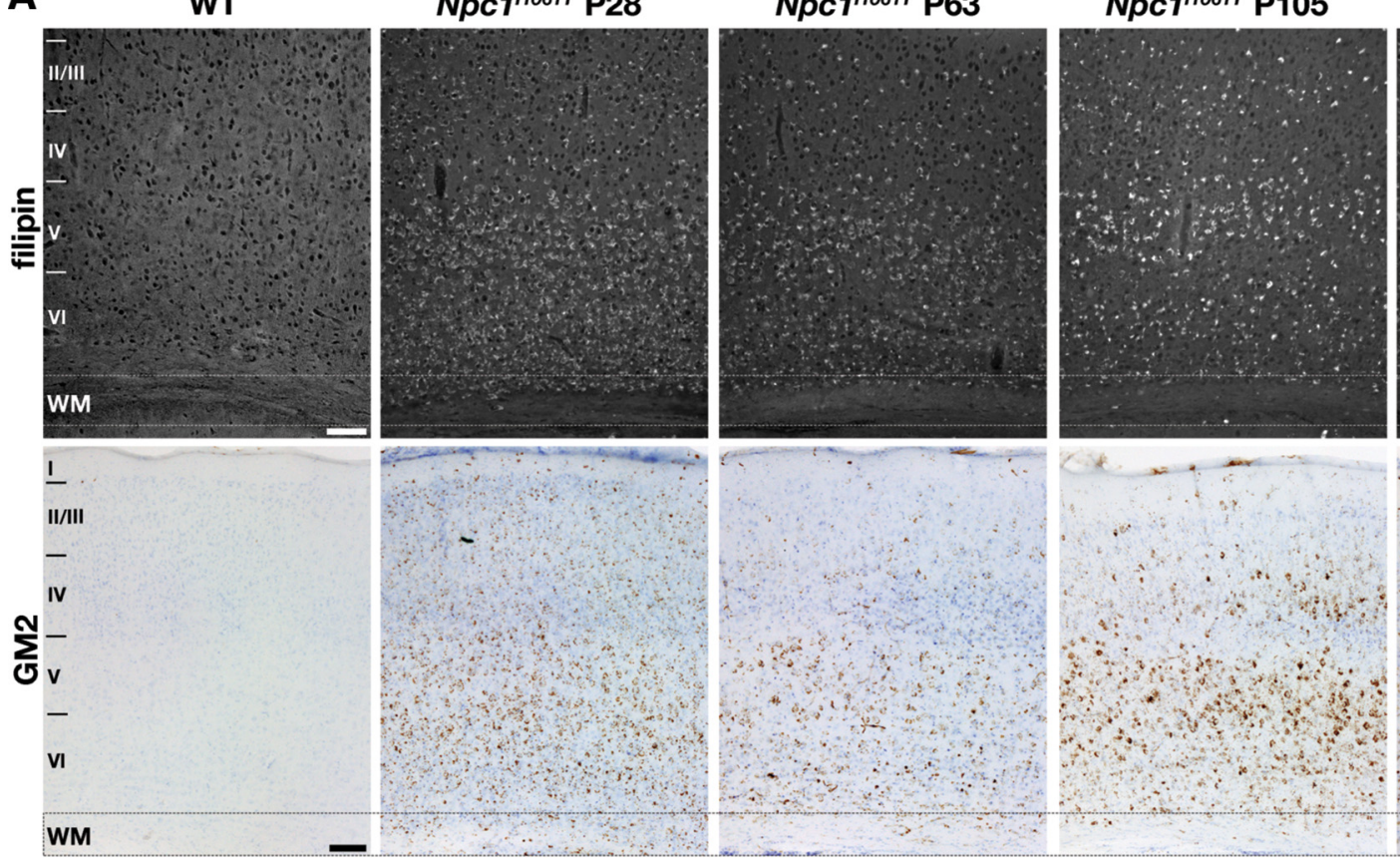

B

Npc1 ${ }^{11061 T}$ P63

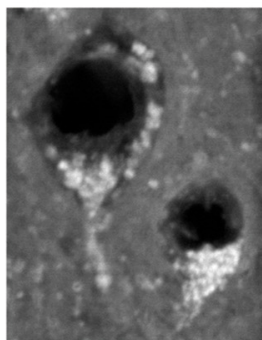

filipin

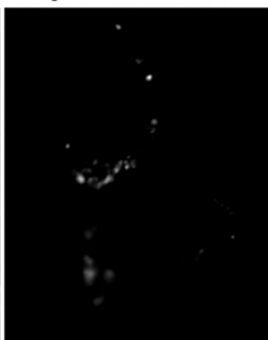

GM2

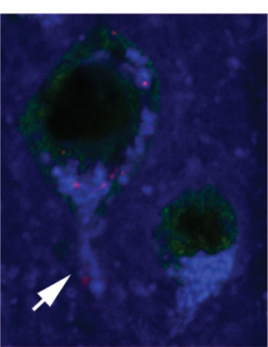

NeuN/GM2/filipin
Npc1 $^{-/-}$P63

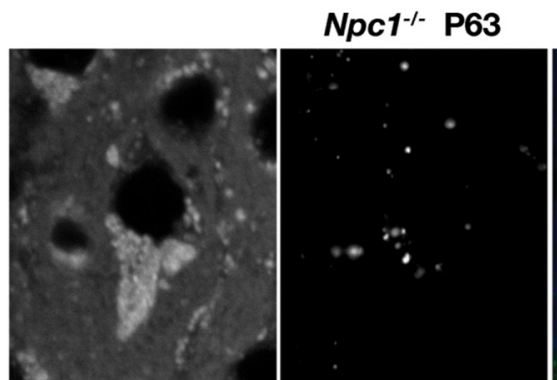

filipin
GM2

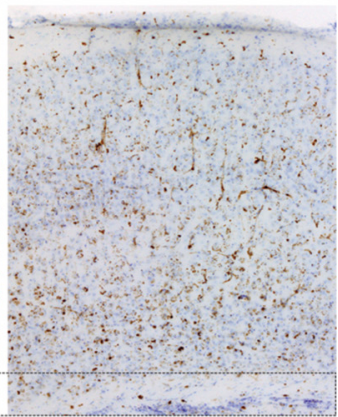

C

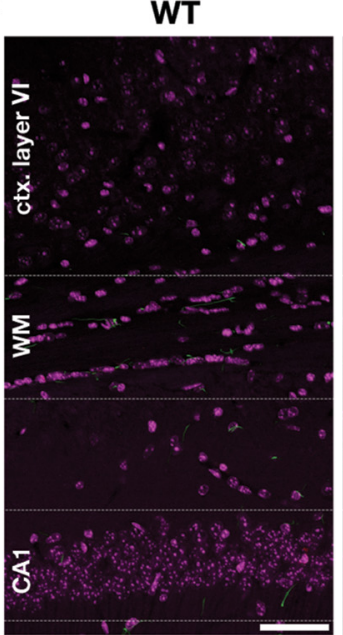

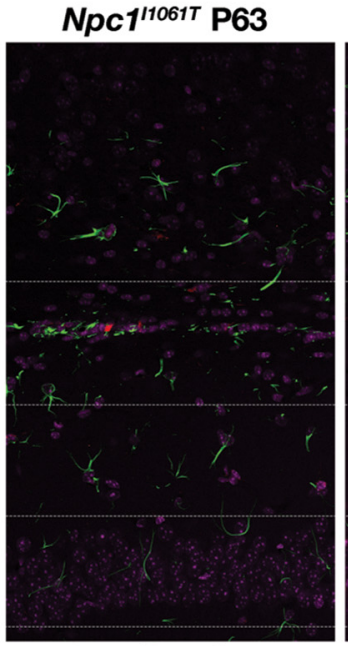

GFAP/CD68/DAPI
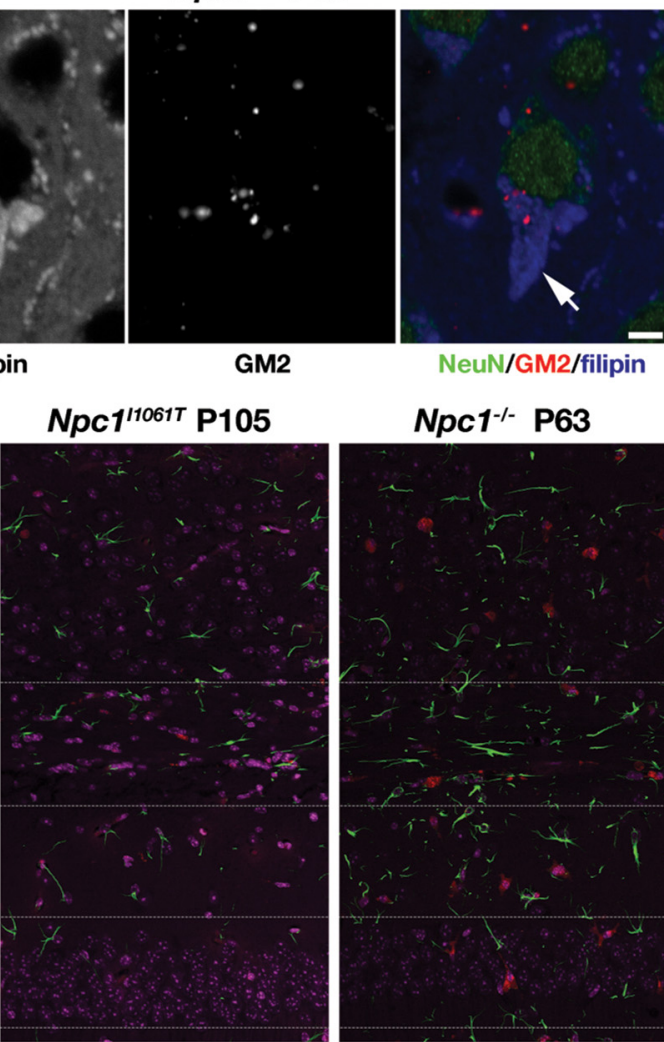

NeuN/GM2/filipin
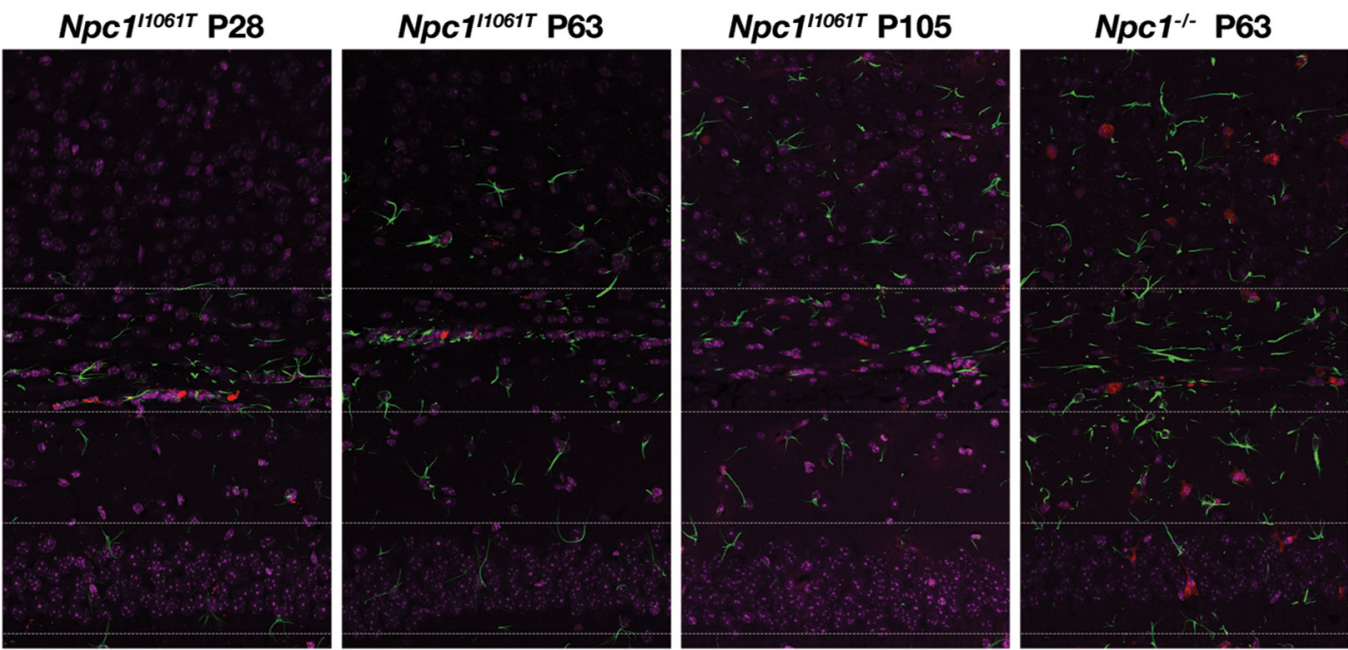

Figure 5. Hallmarks of cerebral neuropathology of $\mathrm{Npc}{ }^{17061 T}$ mice. $A$, Filipin labeling of cholesterol accumulation (top row) and GM2 ganglioside staining (bottom row, brown; NissI nuclear counterstain) within the primary somatosensoryneocortex. B, Immunofluorescencestaining ofneocortical neuronsfrom P63 $\mathrm{Npc}^{17061 T}$ (left) and Npc ${ }^{-1-}$ (right) cholesteroland GM2 gangliosidestoragein theneuronal cell bodies (NeuN + ), as well as withindistended initial axonal segments (meganeurites, whitearrows).C,Microglial(CD68+) andastrocytic(GFAP+) labeling in Npc ${ }^{17061 T}$ micecompared withNpc ${ }^{-1}{ }^{-}$miceinasegment ofdeep somatosensory cortex (layerVI), subcortical white matter, and the adjoining CA1 segment. Images are MIPs of 4.8- $\mu \mathrm{m}$-thickZstacks. WM, White matter; $\mathrm{Ctx}$, cortex; CA1, CA1 region of hippocampus. Scale bars: $A, 100 \mu \mathrm{m} ; \boldsymbol{B}, 5 \mu \mathrm{m} ; C, 50 \mu \mathrm{m}$.

Electron microscopy of murine tissues. Liver and cerebellum were processed for electron microscopy as described previously (Davidson et al., 2009). Lobules corresponding to anterior and nodular zones were manually dissected from $250-\mu \mathrm{m}$-thick sagittal sections from cerebellar vermis.
Purkinje cell density counts. Densities of Purkinje cells were assessed in individual cerebellar lobes (I-X) from three $35-\mu \mathrm{m}$-thick midline sagittal cerebellar sections labeled with $\alpha$-calbindin mouse Ab. Lengths of Purkinje cell layers in individual lobules and Purkinje cells were manually 
A

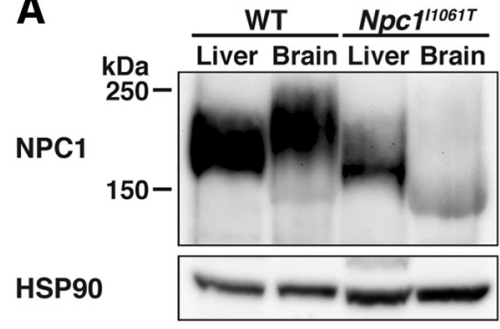

D
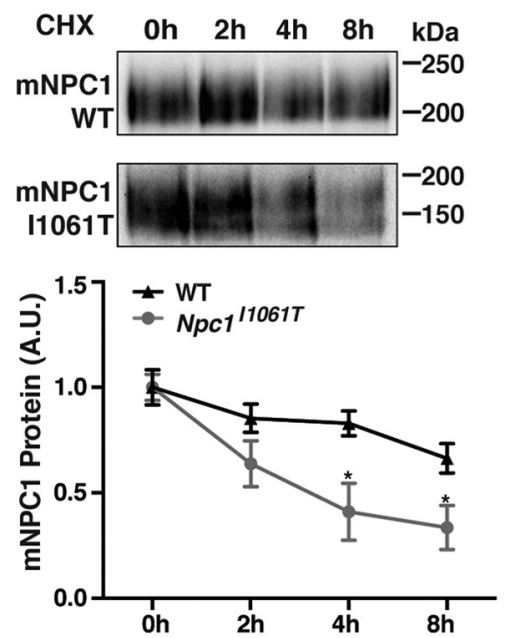

B

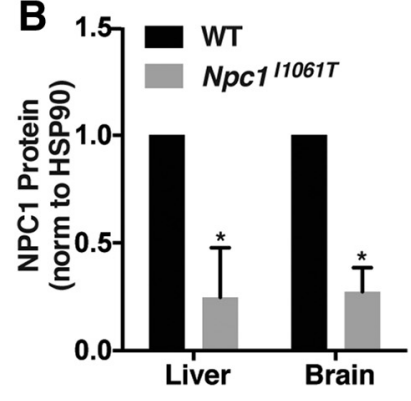

E
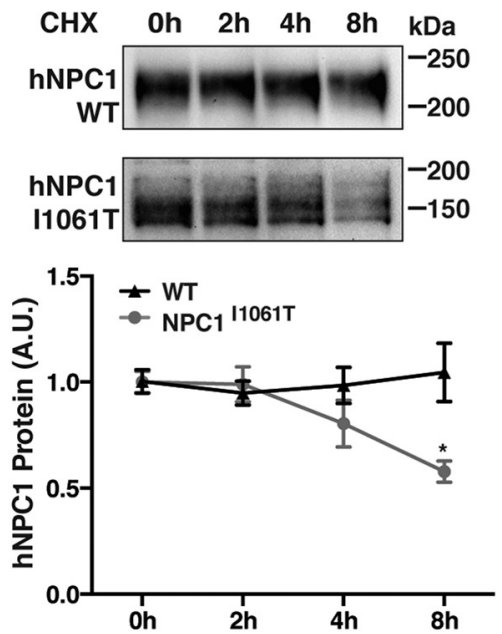
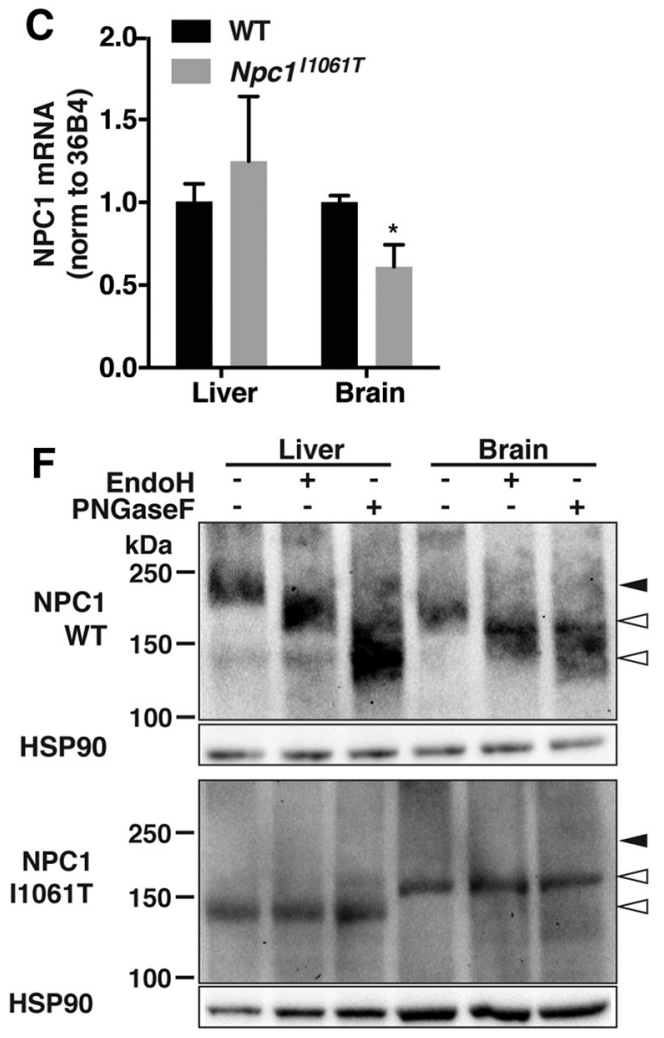

Figure 6. In vivo characterization of NPC1 protein in Npc $7^{11061 T}$ tissues. A, Western blot analysis of WT (50 $\mu \mathrm{g}$ protein) and Npc $7^{17061 T}$ (200 $\mu \mathrm{g}$ protein) tissue homogenate from P28 mice. $\boldsymbol{B}$, Quantification of Western blot analysis in A. C, RT-qPCR analysis of NPC1 mRNA from P28 WT and Np $7^{17061 T}$ tissue. D, Western blot analysis of hepatocytes isolated from P35 mice, treated with 30 $\mu \mathrm{g} / \mathrm{ml} \mathrm{CHX} \mathrm{over} \mathrm{an} 8 \mathrm{~h}$ time course. E, Western blot analysis of WT and NPC $1^{11061 \mathrm{~T}}$ homozygous human skin fibroblasts, treated with $30 \mu \mathrm{g} / \mathrm{ml}$ CHX over an $8 \mathrm{~h}$ time course. $F$, Western blot analysis ofWT (200 $\mu \mathrm{g}$ ) and Npc $7^{17061 T}$ (400 $\mu \mathrm{g}$ of liver, $500 \mu \mathrm{g}$ of brain) tissue homogenate treated with endoglycosidase H (EndoH) and PNGase F. Filled arrowheads indicate glycosidase-resistant species, and open arrowheads indicate glycosidase-sensitive species. ${ }^{*} p<0.05$.

traced/counted using an Olympus BX51 microscope equipped with $4 \times$ (NA 0.13), $10 \times$ (NA 0.30), and $20 \times$ (NA 0.50) objectives and Stereo Investigator software (MBF Biosciences). Densities are shown as the number of Purkinje cells/1 mm of Purkinje cells layer length. Statistical comparisons were calculated for average density values in cerebellar lobules, grouped based on sagittally projected transverse cerebellar zones as described previously (Sillitoe and Joyner, 2007).

Isolation of murine embryonic fibroblasts. Mouse embryos were isolated at day 13.5 and placed in PBS. The head and entrails were removed, and the embryo was minced into small chunks. Chunks were transferred to a $50 \mathrm{ml}$ conical, and $1 \mathrm{ml}$ of trypsin $(0.25 \%$ in EDTA $)$ was added, pipetted to initiate disaggregation. Another $0.5 \mathrm{ml}$ of trypsin was added, and the tissue was digested $15 \mathrm{~min}$ at room temperature with occasional vortexing. The reaction was then neutralized with medium $(10 \%$ heatinactivated fetal serum, $1 \%$ nonessential amino acids, $150 \mu \mathrm{M}$ 1-thioglycerol in DMEM), and supernatant was taken as a sample. Samples were centrifuged at $1000 \mathrm{rpm}$ for $10 \mathrm{~min}$ to pellet cells. Isolated cells were then plated into flasks, $\sim 1.25$ embryos per T150.

Cell culture immunofluorescence. Murine embryonic fibroblasts (MEFs) were plated on $12 \mathrm{~mm}$ circular coverslips in medium in 24-well plates at $5 \times 10^{4}$ cells per well. Twenty-four hours after plating, cells were fixed in $4 \%$ paraformaldehyde for $20 \mathrm{~min}$ and permeabilized with $0.2 \%$ Tween 20 with $10 \%$ normal goat serum in PBS for $30 \mathrm{~min}$. Cells were stained with $\alpha$-NPC1 antibody (rabbit, 1:250, in house), $\alpha$-LAMP1 (rat, 1:500, University of Iowa Hybridoma Bank), and filipin $(0.05 \mathrm{mg} / \mathrm{ml}$, Sigma) for $1 \mathrm{~h}$. Cells were then incubated with rabbit Alexa Fluor 594 and rat Alexa Fluor 488 for $1 \mathrm{~h}$ and mounted with Slowfade (Invitrogen). Images were captured with the $63 \times$ objective on a laser-scanning confocal microscope (LSM 700 URGB two-channel system; Carl Zeiss) with
$405,488,555$, and $635 \mathrm{~nm}$ solid-state lasers coupled to an Axio Imager M2 microscope with a motorized stage and Zen software. Images were captured with channel pinholes adjusted to 1 Airy unit.

Metabolomics. Sample preparation, instrumentation, and quantification of lipids were performed by tandem mass spectrometry as described previously (Fan et al., 2013). For $N p c 1^{I 1061 T}$ heat maps, data were normalized to the average of the P28 WT values for each lipid, and $Z$ scores for each lipid were generated as reported previously (Fan et al., 2013). Heat maps for the strain comparison (see Fig. 10) were generated by normalizing data to C57BL/6 WT and then calculating $Z$ scores.

Treatment of Npc1 fibroblasts with suberanilohydroxamic acid. WT and $N p c 1^{11061 T}$ MEFs were plated in $10 \mathrm{~cm}$ tissue culture plates in growth medium supplemented with $10 \%$ FBS. After a $24 \mathrm{~h}$ incubation, the cells were treated with $10 \mu \mathrm{m}$ suberanilohydroxamic acid (SAHA) or DMSO (vehicle control) for $72 \mathrm{~h}$ in growth medium supplemented with 5.5\% FBS and harvested for Western blot analysis as described previously (Pipalia et al., 2011).

Statistics. Statistical significance was calculated via the two-tailed $t$ test using the Holm-Sidak method, with $p<0.05$ considered to be significant. In addition to the $t$ test, a Bonferroni's post-test correction for multiple comparison errors was applied to all metabolomic data to determine significance between genotypes.

\section{Results}

Npc1 ${ }^{\text {I1061T }}$ knock-in mice have decreased lifespan, reduced body weight, and impaired motor function

To generate the targeting vector to introduce the I1061T point mutation into the murine Npc1 locus, we used a BAC construct and galK-based recombineering as described (Fig. 1A). Recom- 
bination events were confirmed in ES cells by restriction digest and Southern blotting (Fig. 1B), and the T3179C mutation resulting in the $\mathrm{I1061 \textrm {T }}$ substitution was confirmed by sequencing of the mRNA (Fig. 1C). ES cells harboring the mutant allele were then injected into pregnant C57BL/ 6 females, and chimeras were bred with FLPeR C57BL/6 mice to excise the neomycin cassette. Analyses were performed on offspring backcrossed a minimum of five generations into the $\mathrm{C} 57 \mathrm{BL} / 6$ background. When compared with the $N p c 1^{-1-}$ model, $N p c 1^{I 1061 T}$ mice live 59\% longer, with an average lifespan of $125 \mathrm{~d}$, consistent with expression of a partially functional NPC1 protein (Fig. 2A). Like $N p c 1^{-1-}$ mice, $N p c 1^{I 1061 T}$ mice have significantly lower body weight compared with their WT littermates, and growth curves begin to diverge at 10 weeks, revealing progressive weight loss during later stages of disease (Fig. 2B). At approximately 8 weeks of age, there is onset of a visible resting tremor in $N p c 1^{I 1061 T}$ mice, and by 12 weeks, the mice are no longer able to maintain balance on a rotating rod, a test of motor coordination (Fig. 2C).

Npc1 ${ }^{\text {I1061T }}$ mice exhibit neurological and hepatopathological hallmarks of NPC disease

The progressive loss of motor coordination in NPC1 disease is a well established consequence of the stereotypical Purkinje cell loss in the cerebellum (Higashi et al., 1993). To determine whether the neurological phenotype we observed in the $N p c 1^{I 1061 T}$ mice was associated with Purkinje cell degeneration, we performed calbindin $\mathrm{D}$ immunohistochemistry to visualize these neurons in parasagittal cerebellar sections from P28, P63, and P105 mice. In contrast to WT littermates, cerebella from $N p c 1^{I 1061 T}$ mice showed progressive, age-dependent loss of calbindin D staining, predominantly in the anterior lobules, indicating loss of Purkinje cells (Fig. $3 A, B$ ). The progressive Purkinje cell degeneration was also reflected in the age-dependent reduction in calbindin $D$ mRNA expression (Fig. 3C). In the cerebella of P63 and P105 mice, there was a significant loss of Purkinje cells in anterior (P63, $58 \%$ reduction, $p<0.01 ; \mathrm{P} 105,91 \%$ reduction, $p<0.001)$, central (P105, 80\% reduction, $p<0.001$ ), posterior (P105, 65\% reduction, $p<0.001$ ), and nodular (P105, 41\% reduction, $p<$ 0.001 ) zones but no appreciable Purkinje cell loss in lobule $\mathrm{X}$, which is generally preserved even in end-stage disease (Fig. 3B; Langmade et al., 2006; Davidson et al., 2009). Loss of Purkinje cell bodies was accompanied by axonal spheroid formation, dystrophic dendritic abnormalities, and microglial and astrocytic changes in affected cerebellar areas (Fig. 3D). Although the distribution of Purkinje cell loss in the $N p c 1^{11061 T}$ mice was similar to that observed in the $\mathrm{Npcl}^{-/-}$model, the degree of Purkinje cell loss at P63 was less severe than in similarly aged $\mathrm{Npcl}^{-1-}$ mice, findings consistent with delayed onset of impaired motor coor- dination in the knock-in compared with the knock-out model (Langmade et al., 2006).

We then investigated whether Purkinje cells from $N p c 1^{I 1061 T}$ mice displayed the well characterized subcellular abnormalities of NPC1 disease (Higashi et al., 1993). Immunofluorescence staining of cerebellar sections revealed subcellular storage of cholesterol and ganglioside GM2 in Purkinje neurons from P63 $N p c 1^{I 1061 T}$ mice, similar to the pattern observed in the $\mathrm{Npcl}^{-1-}$ model (Fig. 3E). We also observed subcellular ultrastructural pathology in these animals, with the presence of polymembranous storage bodies in Purkinje cells from P63 Npc1 $1^{I 1061 T}$ mice (Fig. 3F; Higashi et al., 1993). In addition, $N p c 1^{I 1061 T}$ mice exhibited cholesterol storage in CD68-positive macrophages (Fig. 4A) and in hepatocytes (Fig. $4 B$ ), cell types critically associated with the progression of the liver disease (Lopez et al., 2012). Electron microscopy similarly revealed the presence of polymembranous storage bodies in both macrophages and hepatocytes (Fig. 4C). Although delayed when compared with $\mathrm{Npcl}^{-1-}$, the macrophage pathology was particularly progressive in this novel model.

We also examined whether cerebral tissues from $N p c 1^{I 1061 T}$ mice exhibited the lipid storage phenotype that is the biochemical hallmark of NPC disease (Walkley and Suzuki, 2004). In neocortex, cholesterol and ganglioside storage was evident in all layers 
A

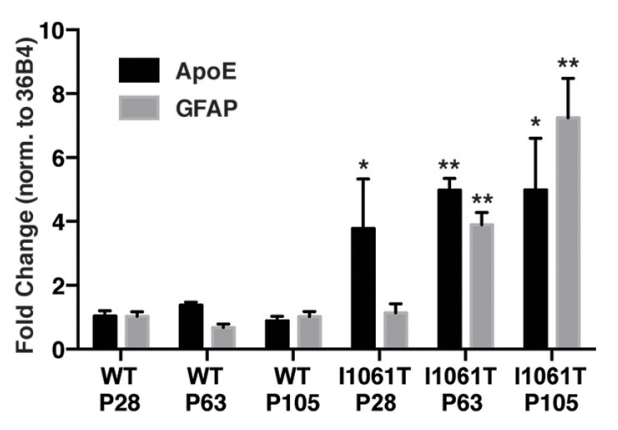

C

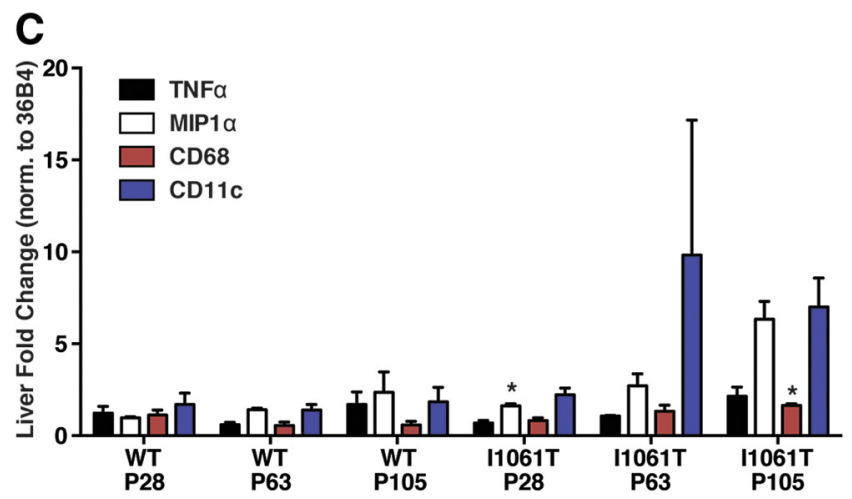

B

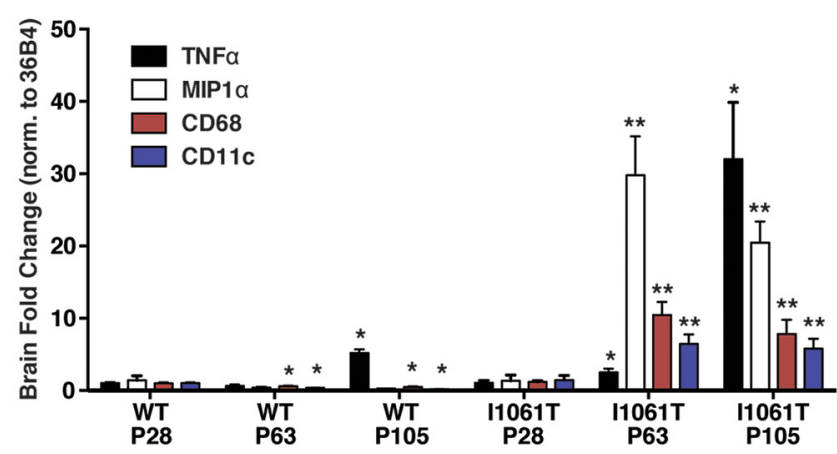

Figure 8. Gene expression of Npc $7^{11061 T}$ brain and liver tissue. $\boldsymbol{A}, \mathrm{ApoE}$ and GFAP mRNA expression in brain. $\boldsymbol{B}$, Expression of markers of cytokine activation (TNF $\alpha$, MIP1 $\alpha$ ) and glial activation (CD68, CD11C) in brain. C, Expression of markers of cytokine activation (TNF $\alpha$, MIP1 $\alpha$ ) and macrophage activation (CD68, CD11C) in liver. Values are normalized to 36B4, and fold change is calculated relative to WT P28 values. ${ }^{*} p<0.5 ;{ }^{* *} p<0.001, N p c 1^{11061 T}$ versus WT.

and was most abundant in layers V and VI (Fig. 5A). A substantial portion of the metabolites localized to neuronal cell bodies; however, we also identified abnormal accumulation in meganeurites, a feature previously described in NPC disease (Fig. 5B). To determine whether the microglia were activated in the $N p c 1^{I 1061 T}$ mice, neocortical sections were stained with CD68 and GFAP, markers that monitor macrophage infiltration in $\mathrm{Npcl}^{-1-}$ brain (Langmade et al., 2006; Lopez et al., 2012). Immunofluorescence staining of neocortical sections also revealed an age-dependent increase in microglial activity and astrocytic reactive changes in $N p c 1^{I 1061 T}$ tissue, as seen by increased CD68 and GFAP signals (Fig. 5C). The progression and spatial pattern of microglial activation, while delayed, is similar to that reported in the $\mathrm{Npcl}^{-1-}$ mouse (Pressey et al., 2012).

\section{The murine NPC1 ${ }^{\text {I1061T }}$ protein is unstable and retained in the ER}

In human NPC1 mutant fibroblasts, the $\mathrm{NPC} 1^{\mathrm{I} 1061 \mathrm{~T}}$ protein is misfolded and targeted for proteasomal degradation. As a result, the half-life of the mutant NPC1 protein is decreased, and the small amount of protein that is present is predominantly localized to the ER (Gelsthorpe et al., 2008). We hypothesized that the murine NPC1 ${ }^{\mathrm{I} 1061 \mathrm{~T}}$ protein shares the same defect. To determine whether tissues from $N p c 1^{I 1061 T}$ mice have decreased NPC1 protein accumulation, we performed Western blotting of liver and brain homogenate. $N p c 1^{I 1061 T}$ mice showed dramatically decreased levels of NPC1 protein in both tissues compared with WT, which was disproportionate to the slight decrease in NPC1 mRNA expression (Fig. 6A-C). This finding is consistent with our previous observation in human $N P C 1^{I 1061 T}$ fibroblasts, in which there was no correlation between $N P C 1^{11061 T}$ transcript abundance and mutant protein levels, indicating that NPC1 protein levels are principally regulated by translational or post-translational mechanisms rather than transcriptional mechanisms (Gelsthorpe et al., 2008). In addition, the NPC1 ${ }^{\mathrm{I} 1061 \mathrm{~T}}$ protein demonstrated an enhanced electrophoretic mobility, suggesting a less mature glycosylation state. Most of the NPC1 ${ }^{\mathrm{I} 1061 \mathrm{~T}}$ protein migrates as a $\sim 140 \mathrm{kDa}$ band, which is the predicted weight of unmodified NPC1, whereas a small proportion of presumably glycosylated NPC $1^{\mathrm{I1061T}}$ protein appears as higher-molecular-weight bands. To determine whether murine NPC1 ${ }^{\text {I1061T }}$ protein has decreased stability, we isolated hepatocytes from WT and $N p c 1^{I 1061 T}$ littermates, treated these primary cells with CHX to block new protein synthesis, and quantified levels of NPC1 protein by Western blotting. Whereas $63 \%$ of WT NPC1 protein was remaining after treatment, only $33 \%$ of NPC $1^{\text {I1061T }}$ protein remained after CHX treatment (Fig. $6 D$ ). These findings phenocopied the reduced stability of the mutant NPC1 protein in human skin fibroblasts derived from a patient homozygous for the $N P C 1^{I 1061 T}$ mutation. The kinetics of the NPC ${ }^{111061 \mathrm{~T}}$ protein degradation in the murine hepatocytes differed slightly from that in human fibroblasts, possibly reflecting cell- or species-specific differences (Fig. 6E). Moreover, digestion of liver and brain homogenate with endoglycosidase $\mathrm{H}$, which removes immature $\mathrm{N}$-linked glycan residues, revealed that a majority of murine NPC1 ${ }^{\mathrm{I} 1061 \mathrm{~T}}$ protein lacks mature glycosylation, indicating that it has been retained in the ER because of misfolding (Fig. $6 F$ ). We also found that the digested NPC1 ${ }^{\text {I1061T }}$ protein from brain homogenate migrates as a higher-molecularweight band compared with liver homogenate, indicating that NPC1 $1^{\text {I1061T }}$ protein may acquire additional post-translational modifications in this organ. It has also been previously shown that the buffers used in the digest reaction alter the apparent mobility of NPC1 bands (Gelsthorpe et al., 2008), which explains the difference in the appearance between Fig. 6, $A$ and $F$. 
A

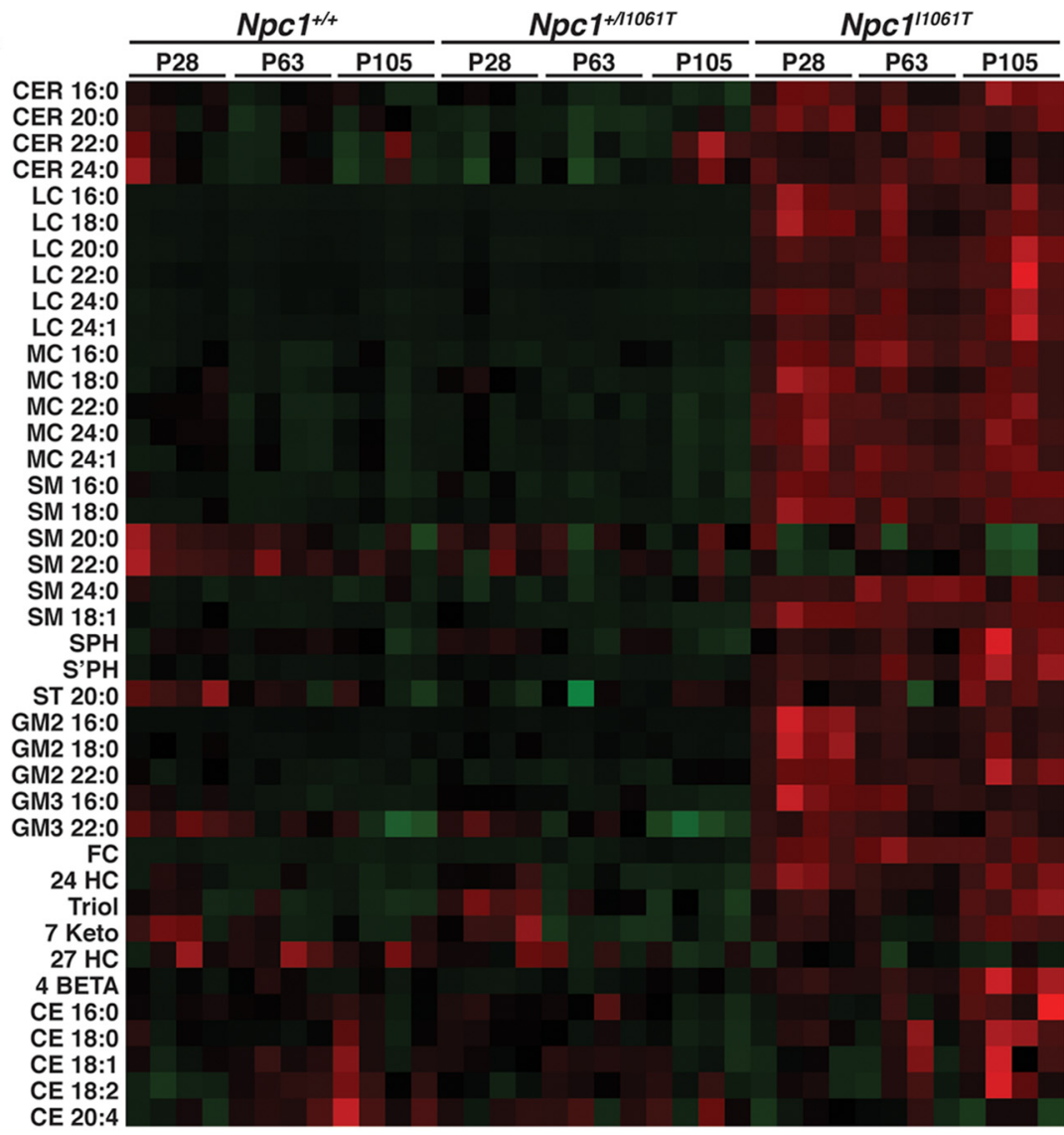

C

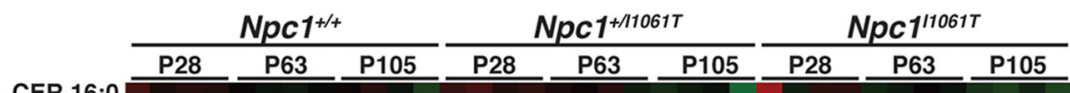

CER 16:0

CER 20:0

CER 22:0

LC 16:0

LC 18:0

LC 20:0

LC 22:0

MC 16:0

MC 18:0

MC 20:0

MC 22:0

MC 24:0

SM 16:0

SM 18:0

SM 20:0

SM 22:0

SM 24:0

SM 18:1

SPH

ST 20:0

GM2 18:0

GM3 18:0

$$
24 \mathrm{HC}
$$

$24 \mathrm{HC}$
Triol

7 Keto

27 HC

CE 16:0

CE 18:0

CE 18:1

CE 18:2

CE 20:4

Npott+ 
Table 1. Lipidomic analysis of $\mathrm{Npc} \mathrm{1}^{11061 T}$ tissues

\begin{tabular}{|c|c|c|c|c|}
\hline \multirow[b]{3}{*}{ CER 16:0 } & \multicolumn{4}{|c|}{ Npc1 $1^{I 1061 T}$ vs WT Liver } \\
\hline & P14 & P28 & P63 & P105 \\
\hline & 1.58 & 1.76 & 1.27 & 2.09 \\
\hline CER 20:0 & 1.60 & 1.64 & 1.32 & 1.48 \\
\hline CER 22:0 & 1.65 & 1.04 & 1.30 & 0.99 \\
\hline CER 24:0 & 1.38 & 1.02 & 1.14 & 1.00 \\
\hline LC 16:0 & 15.86 & 17.02 & 13.01 & 14.47 \\
\hline LC 18:0 & 11.93 & 29.23 & 14.23 & 19.86 \\
\hline LC 20:0 & 5.24 & 10.00 & 9.39 & 16.42 \\
\hline LC 22:0 & 4.40 & 8.63 & 10.11 & 17.73 \\
\hline LC 24:0 & 4.55 & 9.79 & 6.68 & 10.73 \\
\hline LC 24:1 & 6.83 & 11.75 & 14.20 & 20.24 \\
\hline MC 16:0 & 7.38 & 5.10 & 5.87 & 4.91 \\
\hline MC 18:0 & 6.55 & 5.39 & 2.85 & 3.57 \\
\hline MC 22:0 & 4.68 & 2.56 & 2.08 & 2.57 \\
\hline MC 24:0 & 5.52 & 3.38 & 2.30 & 3.18 \\
\hline MC 24:1 & 5.52 & 3.93 & 4.05 & 4.27 \\
\hline SM 16:0 & 2.77 & 2.33 & 2.14 & 2.42 \\
\hline SM 18:0 & 6.55 & 6.03 & 3.79 & 4.61 \\
\hline SM 20:0 & 0.98 & 0.74 & 0.78 & 0.65 \\
\hline SM 22:0 & 1.01 & 0.55 & 0.65 & 0.58 \\
\hline SM 24:0 & 3.39 & 2.07 & 3.23 & 2.41 \\
\hline SM 18:1 & 4.68 & 5.35 & 4.05 & 4.24 \\
\hline SPH & 1.00 & 5.94 & 6.32 & 11.52 \\
\hline S'PH & 4.05 & 6.50 & 7.06 & 14.20 \\
\hline ST 20:0 & 1.13 & 0.77 & 0.65 & 0.98 \\
\hline GM2 16:0 & 16.12 & 95.15 & 30.20 & 38.11 \\
\hline GM2 18:0 & 13.99 & 17.19 & 4.68 & 8.96 \\
\hline GM2 22:0 & 4.84 & 5.23 & 3.31 & 5.69 \\
\hline GM3 16:0 & 6.16 & 2.89 & 2.03 & 1.42 \\
\hline GM3 22:0 & 1.32 & 0.94 & 0.81 & 0.84 \\
\hline FC & 4.35 & 4.33 & 5.02 & 4.30 \\
\hline $24 \mathrm{HC}$ & 2.46 & 2.49 & 1.43 & 2.36 \\
\hline Triol & 1.44 & 1.35 & 1.15 & 2.09 \\
\hline 7 Keto & 0.87 & 0.77 & 0.56 & 1.11 \\
\hline $27 \mathrm{HC}$ & 1.00 & 0.57 & 0.60 & 0.52 \\
\hline 4 BETA & 1.35 & 2.06 & 2.02 & 4.83 \\
\hline CE 16:0 & 0.42 & 0.99 & 1.11 & 2.44 \\
\hline CE 18:0 & 0.42 & 1.15 & 1.41 & 2.31 \\
\hline CE 18:1 & 0.47 & 0.85 & 1.40 & 2.12 \\
\hline CE 18:2 & 0.56 & 1.20 & 1.38 & 2.08 \\
\hline CE 20:4 & 0.89 & 1.01 & 1.13 & 0.98 \\
\hline
\end{tabular}

\begin{tabular}{|c|c|c|c|c|}
\hline \multirow[b]{3}{*}{ CER 16:0 } & \multicolumn{4}{|c|}{ Npc1 ${ }^{11061 T}$ vs WT Brain } \\
\hline & P14 & P28 & P63 & P105 \\
\hline & 1.15 & 1.05 & 0.84 & 0.72 \\
\hline CER 20:0 & 1.06 & 1.24 & 1.02 & 1.11 \\
\hline CER 22:0 & 1.04 & 1.39 & 1.65 & 1.55 \\
\hline CER 24:0 & 1.00 & 1.54 & 1.38 & 1.16 \\
\hline LC 16:0 & 1.78 & 1.85 & 1.80 & 1.99 \\
\hline LC 18:0 & 4.75 & 5.04 & 3.75 & 4.34 \\
\hline LC 20:0 & 0.98 & 0.95 & 0.91 & 0.70 \\
\hline LC 22:0 & 1.47 & 1.35 & 1.11 & 0.84 \\
\hline MC 16:0 & 0.98 & 1.18 & 2.04 & 1.79 \\
\hline MC 18:0 & 0.90 & 1.58 & 2.01 & 1.69 \\
\hline MC 20:0 & 0.74 & 1.10 & 1.23 & 1.51 \\
\hline MC 22:0 & 0.69 & 1.09 & 1.45 & 1.31 \\
\hline MC 24:0 & 0.64 & 1.10 & 1.47 & 1.41 \\
\hline SM 16:0 & 0.85 & 1.12 & 1.23 & 1.52 \\
\hline SM 18:0 & 0.86 & 0.95 & 0.89 & 1.04 \\
\hline SM 20:0 & 1.04 & 1.02 & 1.10 & 1.01 \\
\hline SM 22: 0 & 0.86 & 1.04 & 1.05 & 1.10 \\
\hline SM 24:0 & 0.55 & 0.76 & 0.87 & 0.71 \\
\hline SM 18:1 & 0.84 & 0.92 & 0.88 & 0.89 \\
\hline SPH & 1.75 & 1.55 & 1.61 & 1.82 \\
\hline S'PH & 1.39 & 1.36 & 1.68 & 1.70 \\
\hline S1P & 1.75 & 1.55 & 1.61 & 1.82 \\
\hline ST 20:0 & 1.16 & 0.91 & 0.58 & 0.63 \\
\hline GM2 18:0 & 18.57 & 11.70 & 14.32 & 8.63 \\
\hline GM3 18:0 & 1.65 & 3.41 & 2.42 & 2.87 \\
\hline FC & 0.97 & 0.97 & 0.94 & 1.08 \\
\hline $24 \mathrm{HC}$ & 0.98 & 0.98 & 0.94 & 0.96 \\
\hline Triol & 1.10 & 1.26 & 1.43 & 1.25 \\
\hline 7 Keto & 0.99 & 1.05 & 1.14 & 0.57 \\
\hline $27 \mathrm{HC}$ & 0.87 & 0.52 & 0.61 & 0.58 \\
\hline CE 16:0 & 0.89 & 2.42 & 1.15 & 5.43 \\
\hline CE 18:0 & 0.82 & 1.60 & 1.04 & 2.75 \\
\hline CE 18:1 & 0.77 & 1.51 & 1.08 & 3.16 \\
\hline CE 18:2 & 0.89 & 1.94 & 1.19 & 1.32 \\
\hline CE 20:4 & 0.95 & 1.63 & 1.11 & 1.25 \\
\hline & $p \leq 0.05$ & & & \\
\hline & $p \leq 0.01$ & & & \\
\hline & $p \leq 0.001$ & & & \\
\hline
\end{tabular}

Fold change values of lipids quantified in liver and brain from Npc1 $1^{11061 T}$ mice compared with WT mice of the same age. $n=4$ per group. Light gray, $p \leq 0.05$; dark gray, $p \leq 0.01$; black, $p \leq 0.001$; white, nonsignificant.

To determine whether the subcellular localization of NPC $1^{\text {I1061T }}$ protein is altered, we performed immunofluorescence staining in MEFs. In WT MEFs, NPC1 protein colocalized with a LAMP1-positive, filipin-negative endolysosomal compartment. In contrast, in $N p c 1^{I 1061 T}$ MEFs, the mutant protein was expressed at much lower levels than WT NPC1 protein and displayed a reticular staining pattern that was distinct from filipinpositive lysosomes and most consistent with ER localization (Fig. 7). Together, these data indicate that murine $\mathrm{NPC}^{\mathrm{I} 1061 \mathrm{~T}}$ protein, like the human mutant protein, is misfolded and targeted for ERassociated degradation, preventing its proper targeting to endolysosomes.

Cytokine activation and inflammation in tissues in Npc1 ${ }^{\text {I1061T }}$ mice

A prominent feature of NPC1 disease models is profound inflammatory changes, particularly in brain tissue (Langmade et al., 2006). We quantified inflammatory gene expression by performing RTqPCR on mRNA isolated from brain and liver tissue from $N p c 1^{I 1061 T}$ mice and WT littermates at P28, P63, and P105 (Fig. 8). Npc1 $1^{I 1061 T}$ cerebellum tissue showed increased apolipoprotein E (apoE) and GFAP expression compared with WT that was significant at P63 and P105 (for P63 and P105, $p<0.05$ ), consistent with glial activation known to occur in response to neuronal cell death in NPC1 disease
(Fig. 8A; Baudry et al., 2003). This was accompanied by a dramatic increase in expression of cytokines (TNF $\alpha$ and MIP1 $\alpha$ ) and markers of microglial activation (CD68 and CD11c), particularly late in disease progression (Figs. 3D, 5C, 8B). A similar pattern of induction of inflammatory gene expression was present in liver tissue (Fig. 8C). With the exception of apoE expression, no significant changes in cholesterol homeostatic gene expression were observed in either brain (Fig. 8A) or liver (data not shown) tissue.

Lipid accumulation in tissues of $\mathrm{Npc1}{ }^{\text {I1061T }}$ mice

Previous studies have shown that multiple cholesterol-derived metabolites and sphingolipid species accumulate in liver and brain of the $\mathrm{Npcl}^{-/-}$mouse model, and abundance of many species increases with disease progression (Pentchev et al., 1980; Goldin et al., 1992; Porter et al., 2010; Fan et al., 2013). To determine whether the I1061T missense mutation led to a similar lipid storage phenotype, we broadly surveyed cholesterol-derived metabolites and sphingolipid de novo and recycling pathways in liver and brain tissue from the $N p c 1^{I 1061 T}, N p c 1^{+/ I 1061 T}$, and WT littermates (P14, P28, P63, and P105) and from Npc1 ${ }^{-1-}$ mice and WT littermates (P49). Lipid classes quantified by tandem mass spectrometry included sphingoid bases, ceramides, sphingomyelins, monohexosylceramides and dihexosylceramides, gangliosides, sulfatides, unesterified and esterified cholesterol, and 
A

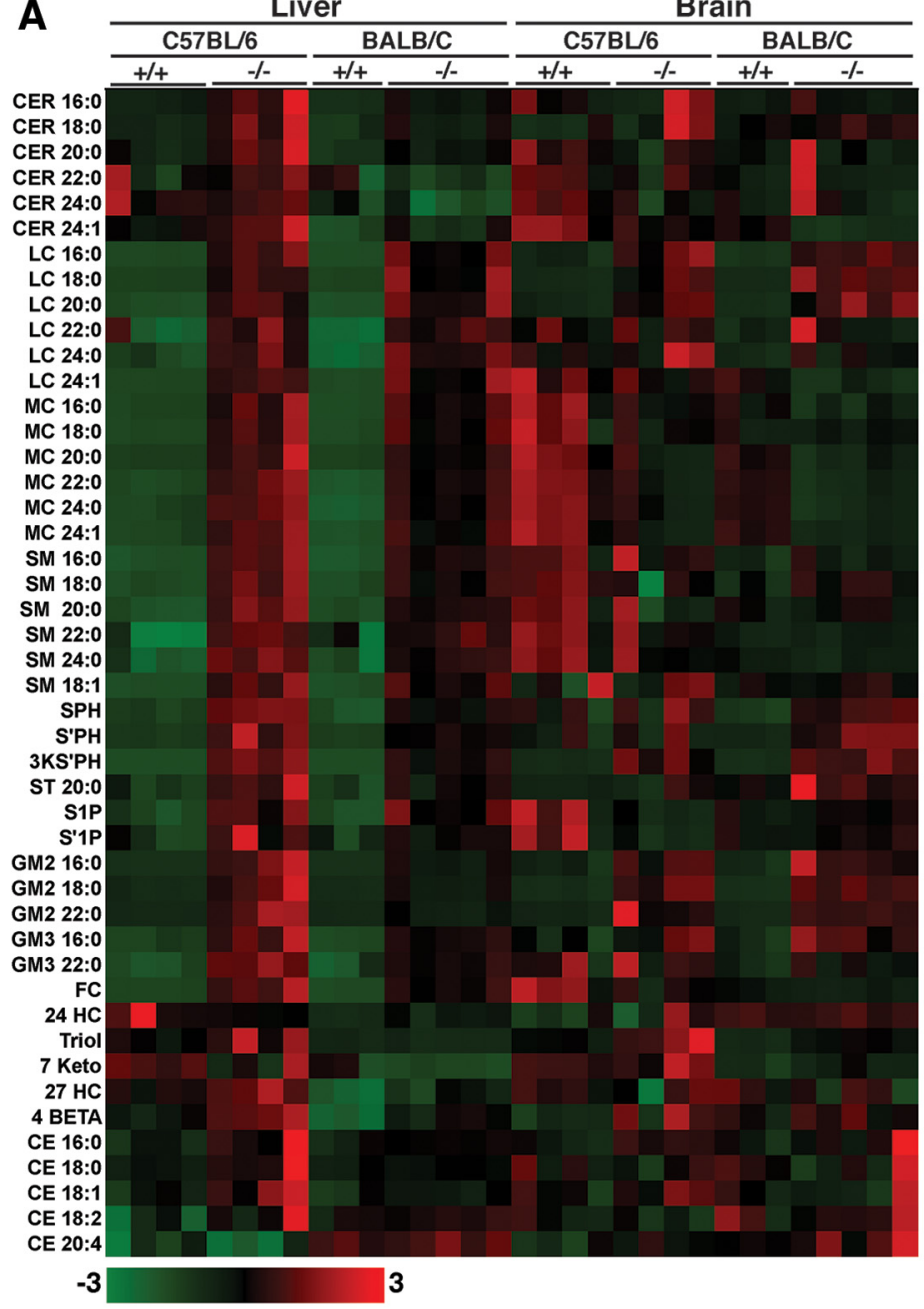

$\mathbf{B}$

\begin{tabular}{|c|c|c|c|c|c|c|}
\hline & \multicolumn{2}{|c|}{ BALB/C WT } & \multicolumn{2}{|c|}{ C57BL/6 -/- } & \multicolumn{2}{|c|}{ BALB/C -/- } \\
\hline & Liver & Brain & Liver & Brain & Liver & Brain \\
\hline CER 16:0 & 0.90 & 1.07 & 7.34 & 1.10 & 4.48 & 1.11 \\
\hline CER 18:0 & 1.00 & 0.73 & 6.30 & 2.19 & 3.23 & 1.26 \\
\hline CER 20:0 & 1.03 & 1.07 & 3.25 & 0.74 & 1.66 & 1.21 \\
\hline CER 22:0 & 1.04 & 1.11 & 1.27 & 0.79 & 0.67 & 1.27 \\
\hline CER 24:0 & 1.03 & 1.08 & 1.01 & 0.67 & 0.87 & 1.17 \\
\hline CER 24:1 & 0.91 & 1.16 & 2.59 & 0.63 & 2.43 & 0.38 \\
\hline LC 16:0 & 0.97 & 1.13 & 37.70 & 3.04 & 63.19 & 4.34 \\
\hline LC 18:0 & 0.92 & 1.19 & 34.43 & 11.10 & 86.15 & 26.71 \\
\hline LC 20:0 & 1.11 & 1.15 & 20.00 & 4.78 & 39.67 & 11.50 \\
\hline LC 22:0 & 1.20 & 1.14 & 2.67 & 1.26 & 8.53 & 3.04 \\
\hline LC 24:0 & 1.09 & 1.09 & 4.49 & 1.57 & 12.77 & 2.05 \\
\hline LC 24:1 & 0.94 & 1.13 & 35.75 & 0.76 & 84.36 & 0.46 \\
\hline MC 16:0 & 0.90 & 1.18 & 21.86 & 0.60 & 74.01 & 0.57 \\
\hline MC 18:0 & 0.91 & 1.20 & 42.84 & 0.70 & 49.27 & 0.94 \\
\hline MC 20:0 & 0.92 & 1.18 & 26.64 & 0.42 & 25.70 & 0.36 \\
\hline MC 22:0 & 0.94 & 1.16 & 9.60 & 0.37 & 10.70 & 0.23 \\
\hline MC 24:0 & 0.91 & 1.14 & 7.97 & 0.38 & 15.81 & 0.24 \\
\hline MC 24:1 & 0.78 & 1.23 & 15.94 & 0.22 & 40.31 & 0.11 \\
\hline SM 16:0 & 0.96 & 1.11 & 12.47 & 1.01 & 10.77 & 1.20 \\
\hline SM 18:0 & 1.04 & 1.03 & 21.82 & 0.78 & 12.72 & 1.19 \\
\hline SM 20:0 & 1.04 & 1.11 & 6.68 & 0.76 & 3.38 & 1.02 \\
\hline SM 22:0 & 1.06 & 1.18 & 3.25 & 0.72 & 1.75 & 1.08 \\
\hline SM 24:0 & 1.02 & 1.21 & 2.77 & 0.68 & 2.06 & 0.74 \\
\hline SM 18:1 & 0.99 & 0.74 & 26.38 & 1.09 & 20.18 & 1.07 \\
\hline SPH & 0.98 & 1.11 & 5.93 & 1.19 & 3.95 & 1.68 \\
\hline S'PH & 0.96 & 1.11 & 29.88 & 1.14 & 19.59 & 1.93 \\
\hline 3KS'PH & 0.94 & 1.11 & 1086.61 & 11.71 & 764.06 & 18.37 \\
\hline ST 20:0 & 1.04 & 0.98 & 3.02 & 1.36 & 1.93 & 1.64 \\
\hline S1P & 1.01 & 1.23 & 4.33 & 0.30 & 4.18 & 1.12 \\
\hline S'1P & 1.10 & 1.24 & 3.32 & 0.29 & 1.70 & 1.11 \\
\hline GM2 16:0 & 1.14 & 1.14 & 265.95 & 2.61 & 168.16 & 3.36 \\
\hline GM2 18:0 & 1.31 & 1.18 & 86.88 & 15.60 & 57.65 & 21.32 \\
\hline GM2 22:0 & 0.97 & 1.30 & 232.94 & 10.88 & 36.83 & 20.59 \\
\hline GM3 16:0 & 0.94 & 1.26 & 13.04 & 2.31 & 13.31 & 3.48 \\
\hline GM3 22:0 & 0.93 & 1.28 & 5.21 & 1.25 & 2.82 & 2.32 \\
\hline $\mathrm{FC}$ & 0.98 & 1.15 & 12.89 & 0.64 & 10.23 & 0.88 \\
\hline $24 \mathrm{HC}$ & 1.21 & 0.83 & 0.28 & 1.38 & 4.43 & 0.99 \\
\hline Triol & 1.04 & 1.11 & 3.97 & 2.87 & 0.66 & 2.61 \\
\hline 7 Keto & 0.98 & 1.06 & 0.66 & 1.23 & 0.20 & 1.83 \\
\hline $27 \mathrm{HC}$ & 1.00 & 1.04 & 1.49 & 0.92 & 1.36 & 0.88 \\
\hline 4 BETA & 0.92 & 0.99 & 2.89 & 1.61 & 4.61 & 1.12 \\
\hline CE 16:0 & 1.08 & 1.06 & 4.03 & 1.40 & 1.46 & 1.43 \\
\hline CE 18:0 & 1.06 & 1.06 & 6.23 & 0.91 & 1.37 & 0.92 \\
\hline CE 18:1 & 1.04 & 1.10 & 4.32 & 1.22 & 1.46 & 1.00 \\
\hline CE 18:2 & 1.05 & 1.08 & 1.76 & 0.79 & 1.15 & 1.04 \\
\hline CE 20:4 & 0.90 & 0.86 & 0.83 & 1.37 & 1.10 & 1.42 \\
\hline & & & & & & \\
\hline & 0.01 & & & & & \\
\hline & $p \leq 0.001$ & & & & & \\
\hline
\end{tabular}

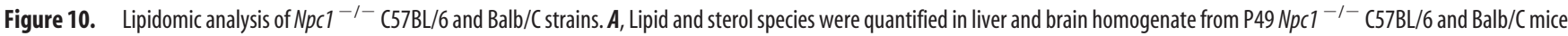
via LC-MS/MS, and heat maps were generated as described in Materials and Methods. Values were normalized to WT C57BL/6. Each tile represents a single animal ( $n=3-5$ per group). Zscores are represented in a gradient color scale; green represents the lowest value $(-3)$, black represents " 0 " value, and red represents the highest value $(+3)$. $\boldsymbol{B}$, Fold change values of lipids quantified in $\boldsymbol{A}$, normalized to WT C57BL/6 mice. Significance was calculated via Student's $t$ test, comparing Npc1 ${ }^{-1-}$ mice with their strain WT littermates. Blue, $p<0.05 ;$ green, $p<0.01 ;$ purple, $p<0.001$; white, nonsignificant.

oxysterols. The metabolomic profiles of brain and liver tissues from $N p c 1^{+/ 11061 T}$ and WT littermates were very similar, consistent with previous profiling of heterozygotes in the $\mathrm{Npcl}^{-1-}$ mouse strain (Fig. 9; Fan et al., 2013). The only significant differences were increased cholesteryl ester $(16: 0,18: 0$, and 18:1) species in brain tissue in P14 and P28 Npc1 $1^{+/ 11061 T}$ mice (Fig. 9C,D). In contrast, metabolomic profiling revealed marked differences between $N p c 1^{I 1061 T}$ mice and age-matched WT littermates (Fig. 9, Table 1). A broad range of lipids accumulated in the liver tissue of P14 $N p c 1^{I 1061 T}$ mice: lactosylceramides (16:0 and 18:0), monohexosylceramides (16:0, 20:0, 22:0, 24:0, and 24:1), sphingomyelins (16:0, 18:0, and 24:0), sphingoid bases (sphinganine and sphingosine), gangliosides (GM2 16:0 and 18:0; GM3 16:0), unesterified cholesterol, and 24(S)-hydroxycholesterol (Fig. 9B). The profound lipid storage in the suckling P14 mice likely reflects the high lipid content of the mouse milk (Silverman et al., 1992) since the lipid storage partially resolved after the mice were weaned at P21. In the liver tissue of older $N p c 1^{I 1061 T}$ mice, there was age-dependent accumulation of multiple sphingolipid species. Significant increases were found among cer- amide (24:0), monohexosylceramides (16:0, 20:0, 22:0, 24:0, and 24:1), lactosylceramides (20:0 and 22:0), sphingomyelins (18:1 and 24:0), sphingosine, and gangliosides (GM2 16:0, GM2 22:0, and GM3 16:0; Fig. 9A). The sphingolipid accumulation was accompanied by significant increases in unesterified cholesterol, $24(S)$-hydroxycholesterol, and $3 \beta, 5 \alpha, 6 \beta$-cholestan-triol (Table 1, Fig. 9A). Sphingolipids were also elevated in the brain tissue of the $N p c 1^{I 1061 T}$ mice, with significant increases found in lactosylceramide (20:0), sulfatide (20:0), sphinganine, and GM3 ganglioside (GM3 18:0) species (Fig. 9C). No significant differences in cholesterol or oxysterol species were detected in bulk brain tissue.

Although the sphingolipid and cholesterol storage phenotype in the $N p c 1^{I 1061 T}$ mice was consistent with findings previously reported in the $\mathrm{Npcl}^{-/-}$mice (Hùlková et al., 2005; Fan et al., 2013), we were intrigued by the observation that $N p c 1^{I 1061 T}$ mice principally accumulate monohexosylceramides and lactosylceramides in brain and liver tissues, whereas $\mathrm{Npcl}^{-1-}$ mice store relatively more gangliosides (GM2 and GM3; Table 1, Fig. 9). To assess whether the distinct lipid storage patterns reflected the difference between a partially functional NPC1 missense muta- 
A
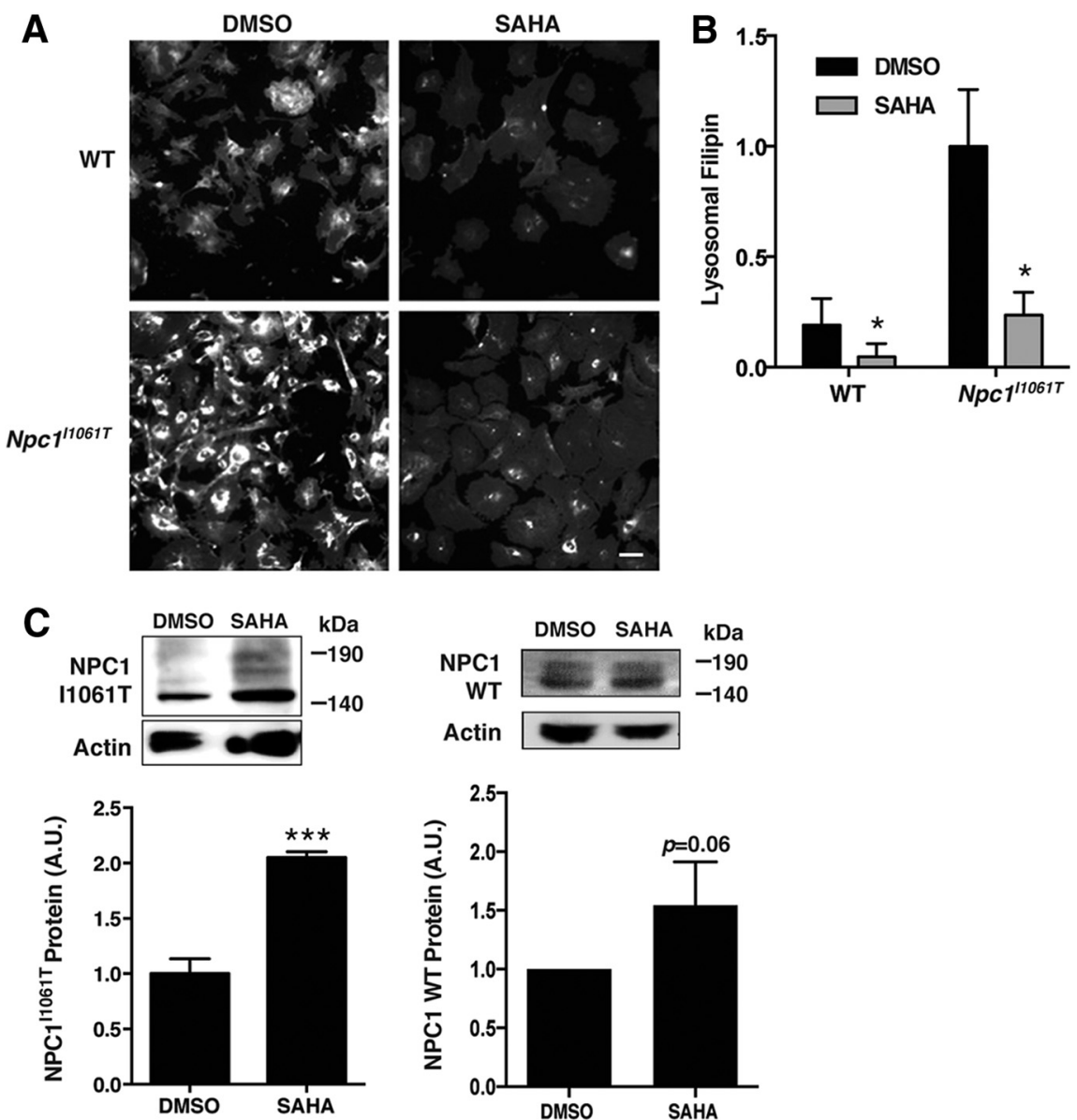

corrects the overall defect in cholesterol regulation (Pipalia et al., 2011). These changes were accompanied by increased expression of $\mathrm{NPC} 1^{\mathrm{I} 1061 \mathrm{~T}}$ mutant protein. To determine whether the murine $\mathrm{NPC}^{\mathrm{I}}{ }^{\mathrm{I} 061 \mathrm{~T}}$ protein in the knock-in mice responded in a similar manner as human NPC $1^{\text {I1061T }}$ fibroblasts to a proteostatic therapy, we isolated MEFs from day 13.5 $N p c 1^{11061 T}$ and WT littermate embryos and treated them with SAHA, and filipin labeling of late endosomes/lysosomes was quantified as described previously (Pipalia et al., 2011). Compared with DMSO vehicle controls, SAHA-treated $N p c 1^{11061 T}$ MEFs had reduced free cholesterol storage, as determined by filipin staining (Fig. 11 A, B). A similar effect was observed in WT cells in which we have previously shown that half of newly synthesized NPC1 is normally degraded (Gelsthorpe et al., 2008). We found that the decrease in lysosomal-free cholesterol in SAHA-treated $\mathrm{Npcl}^{I 1061 \mathrm{~T}} \mathrm{MEFs}$ was attributable to an increase in the abundance of NPC1 ${ }^{\mathrm{I} 1061 \mathrm{~T}}$ protein, as shown by Western blot analysis (Fig. 11C). We also observed that SAHA treatment increases the amount of high-molecular-weight NPC1 ${ }^{\text {I1061T }}$ protein, which likely corresponds to glycosylated, mature protein that is appropriately localized to the lysosome. A trend toward increased NPC1 protein was likewise observed in the SAHA-treated WT MEFs.

\section{Discussion}

Herein, we generated and characterized a novel NPC1 disease model, the Npc1 $1^{\text {IIO61T }}$

tion and a null mutation or differences in genetic background $\left(\mathrm{Npcl}{ }^{I 1061 \mathrm{~T}}\right.$ and $\mathrm{Npcl}^{-/-}$mice are hosted in the $\mathrm{C} 57 \mathrm{BL} / 6$ and $\mathrm{BALB} / \mathrm{c}$ strains, respectively), we obtained brain and liver tissues from $\mathrm{NpCl}^{-1-}$ mice backcrossed into the C57BL/6 background. Metabolomic profiling was performed in $\mathrm{P} 49 \mathrm{Npcl}^{-1-}$ mice in both genetic backgrounds and demonstrated that although there are only minor differences between the $\mathrm{BALB} / \mathrm{c}$ and $\mathrm{C} 57 \mathrm{BL} / 6 \mathrm{WT}$ lipid profiles, livers from $\mathrm{C} 57 \mathrm{BL} / 6 \mathrm{Npcl}^{-1-}$ mice accumulate more ceramides (16:0, 18:0, 20:0, and 24:1), monohexosylceramides (22:0 and 24:0), sphingomyelins (16:0, 18:0, 20:0, and 24:0), sphingoid bases (SPH, S'PH, and 3-keto $S^{\prime} \mathrm{PH}$ ), gangliosides (GM2 16:0, 18:0, and 22:0; GM3 16:0 and 22:0), free cholesterol, 24(S)-hydroxycholesterol, $4 \beta$-hydroxycholesterol, and cholesterol ester (18:1) compared with their BALB/c Npc1 ${ }^{-1-}$ counterparts (Fig. 10). Fewer differences were seen in brain tissue, where $\mathrm{C} 57 \mathrm{BL} / 6 \mathrm{Npcl}^{-1-}$ mice accumulate more ceramide (24:1), lactosylceramide (24:1), and $3 \beta, 5 \alpha, 6 \beta$-cholestan-triol (Fig. 10).

\section{Treatment with HDAC inhibitors corrects the cholesterol} storage phenotype in $\mathrm{Npcl}^{\mathrm{I1061 \textrm {T }}} \mathrm{MEFs}$

In recent studies, we showed that treatment of human NPC1 mutant cells with certain HDAC inhibitors, including the nonselective HDAC inhibitor SAHA, leads to clearance of excess cholesterol and other lipids from late endosomes/lysosomes and knock-in mouse. Introduction of the I1061T missense mutation into the murine NPC1 locus destabilized the NPC1 protein and prevented targeting to late endosomes/lysosomes, mimicking the effects of this mutation in human fibroblasts. Phenotypically, the reduced lifespan, altered growth curves, and progressive decline in motor coordination were all consistent with NPC1 disease, though milder than the severe infantile form of the disease modeled by the BALB/c $\mathrm{Npcl}^{-1-}$ mouse. Similar to the $\mathrm{Npcl}^{-/-}$ mice, we identified a progressive and complex neuropathology, including stereotypic Purkinje cell loss in the cerebella of $N p c 1^{I 1061 T}$ mice, which was antecedent to motor dysfunction and is a neuropathological hallmark of the disease (Higashi et al., 1993; Vanier, 2010). The neurological phenotype was accompanied by astrogliosis, inflammatory gene expression, and storage of cholesterol-derived and sphingolipid species in liver and brain tissues, mirroring the changes reported in human NPC1 disease (Vanier, 1983, 1999; Walkley and Suzuki, 2004; Cologna et al., 2014). In summary, this novel mouse model faithfully recapitulates disease caused by the human NPC1 ${ }^{\mathrm{I} 1061 \mathrm{~T}}$ mutation and provides a powerful tool for preclinical evaluation of proteostatic therapies for NPC1 disease. Moreover, the $N p c 1^{11061 T}$ knock-in mouse may have broader use as a more general model for the study of protein misfolding in vivo. 
Compared with the BALB/c Npcl ${ }^{-/-}$mouse, the phenotype

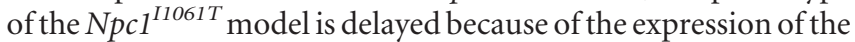
partially functional NPC1 ${ }^{\text {I1061T }}$ protein. Whereas WT and $N p c 1^{11061 \mathrm{~T}}$ mice express similar levels of NPC1 mRNA, NPC1 protein levels are sharply reduced in liver and brain tissues from $N p c 1^{I 1061 T}$ mice. The reduced half-life of the murine NPC1 $1^{\text {I1061T }}$ protein and the endoglycosidase $\mathrm{H}$ sensitivity pattern, indicating failure of the mutant protein to process to a post-ER compartment, is consistent with our previous finding of reduced NPC1 protein stability in $\mathrm{NPC} 1{ }^{\mathrm{I1061T}}$ human skin fibroblasts and demonstrates that a majority of $\mathrm{NPC}^{\mathrm{In}}{ }^{\mathrm{In} 1 \mathrm{~T}}$ protein is misfolded and targeted for degradation (Gelsthorpe et al., 2008). The immunofluorescence staining pattern for the NPC $1{ }^{\text {I1061T }}$ protein, which revealed that the majority of the mutant protein failed to colocalize with LAMP1, a late endosomal/lysosomal marker, also supports a model in which the mutant protein is retained within the ER. Intriguingly, we found differences in the electrophoretic mobility of WT and NPC1 ${ }^{\mathrm{In} 1061 \mathrm{~T}}$ proteins from liver and brain tissues. Endoglycosidase $\mathrm{H}$ and PNGase F digestion of WT protein from these tissues suggests that the NPC1 protein may be differentially glycosylated in the liver and brain. The NPC1 ${ }^{\mathrm{I} 1061 \mathrm{~T}}$ protein is sensitive to both glycosidases in both tissues, suggesting that its impaired folding prevents trafficking through the ER and the addition of N-linked sugar residues. The higher molecular weight of NPC1 ${ }^{\mathrm{I1061T}}$ in brain tissue also suggests this protein may be subject to other post-translational modifications. At present, the relevance of such tissue-specific differences in protein modification to normal physiology or disease pathophysiology is uncertain.

CNS lipid storage is central to the pathophysiology of NPC disease and precedes the inflammation and microglial activation that accompany neuronal loss (Reid et al., 2004). Neuropathological assessment and metabolomic analysis of brains from $N p c 1^{I 1061 T}$ knock-in mice revealed age-dependent accumulation of a broad range of sphingolipid classes, notably sphingoid bases, monohexosylceramides and dihexosylceramides, sphingomyelins, and gangliosides. This pattern of storage is similar to the brain tissue profile previously reported for $\mathrm{Npcl}^{-I-}$ mice (Fan et al., 2013), demonstrating that the knock-in mouse faithfully models NPC1 disease. Although the general consensus is that the primary defect in NPC1 disease is impaired endolysosomal cholesterol export, the cholesterol accumulation is invariably accompanied by secondary storage of sphingolipids (Pentchev et al., 1980, 1984; Vanier, 1983, 1999; Goldin et al., 1992), perhaps caused by the well established biophysical association of cholesterol and sphingolipids in membrane bilayers. The finding that miglustat, a partial inhibitor of glucosylceramide synthase, provides disease amelioration in NPC1 animal models and the fact that limiting synthesis of complex gangliosides leads to reduced cholesterol accumulation imply a critical role for sphingolipid storage in disease pathogenesis (Zervas et al., 2001; Gondré-Lewis et al., 2003; Zhou et al., 2011; Stein et al., 2012; Lee et al., 2014). In contrast to the sphingolipid species, unesterified cholesterol levels in bulk brain tissue are not elevated. Rather, cholesterol storage is evident only by cytochemical analysis of brain tissue sections, predominantly in nuclei containing large neurons that have high obligate rates of cholesterol flux (Dietschy and Turley, 2004).

The $N p c I^{I 1061 T}$ mice similarly exhibit profound lipid storage in peripheral tissues that is a prominent feature in NPC1 animal models and human NPC1 disease (Pentchev et al., 1980; Vanier, 1983; Zervas et al., 2001; Maue et al., 2012; Fan et al., 2013). As in the brain tissue, sphingolipid storage in liver tissue steadily in- creases from P28 to P105, which correlates with disease progression, but, in contrast to brain tissue, is accompanied by increased unesterified cholesterol in bulk tissue. Along with increased cholesterol stores, there is an attendant elevation of $3 \beta, 5 \alpha, 6 \beta-$ cholestan-triol, a nonenzymatic oxidation product that is an NPC1-specific biomarker of disease (Porter et al., 2010; Jiang et al., 2011), which reflects the unique intersection of elevated unesterified cholesterol and oxidative stress in NPC disease (Zampieri et al., 2009; Zhang et al., 2008; Smith et al., 2009).

An unexpected finding was the massive lipid storage in the suckling P14 knock-in mice. The elevation was transient, as cholesterol and sphingolipid content were reduced after weaning (e.g., in P28 mice), strongly implicating the high lipid content of the mouse milk (Silverman et al., 1992). Moreover, the lipid storage in the suckling mice was observed in liver but not in brain tissue, further supporting an exogenous origin for the lipid, since dietary cholesterol does not cross the blood-brain barrier (Dietschy and Turley, 2004). The lipid storage phenotype in liver tissue in the neonatal knock-in mice closely mirrors the profound cholesterol storage in human NPC1 neonates, approximately half of whom present with prolonged jaundice or hepatosplenomegaly (Vanier, 2010).

The genetic background of $N p c 1^{11061 T}$ mice appears to have profound modulatory effects on the NPC1 disease phenotype. Initially, the knock-in mice were backcrossed in the BALB/c strain to permit comparison with the $\mathrm{Npcl}^{-I-}$ mice in the same background. Although the NPC1 disease phenotype (e.g., tremor and reduced lifespan) was readily apparent in the mice in the mixed 129/BL6 background, this phenotype was markedly attenuated once backcrossed into the BALB/c background (our unpublished observations A. Lieberman and D. Ory). In this genetic background, there was no overt neurological phenotype in 6-month-old mice, and disease was only detectable neuropathologically (data not shown), prompting us to re-establish the knock-in mice in the more permissive C57BL/6 background. Consistent with this finding, metabolomic profiling of the $\mathrm{NpCl}^{-I-}$ mice revealed significant differences in the extent of cholesterol and sphingolipid storage between the different genetic backgrounds. Compared with $\mathrm{Npc1}^{-1-}$ mice in the BALB/c background, $\mathrm{NpCl}^{-1-}$ mice in the C57BL/6 background displayed an increased accumulation of ceramide species, sphingomyelins, sphingoid bases, gangliosides, free cholesterol, and oxysterols in peripheral tissues. We hypothesize that the $\mathrm{BALB} / \mathrm{c}$ strain harbors a modifier gene that confers protection against NPC disease (Collins et al., 2006). This putative modifier gene could help stabilize the NPC1 ${ }^{\mathrm{I} 1061 \mathrm{~T}}$ protein in the ER by modulating endogenous chaperones (Yang et al., 2013), allowing more time for the NPC1 $1^{\text {I1061T }}$ protein to achieve proper conformation for entry into the post-ER secretory pathway, and ultimately be targeted to endolysosomes. Alternatively, the modifier gene might act to decrease subcellular lipid accumulation, either by regulating synthesis/processing of sphingolipids or by facilitating endolysosomal cholesterol release through NPC1-independent trafficking pathways (Abi-Mosleh et al., 2009; Cianciola et al., 2013). This variable penetrance of the NPC1 phenotype in the different genetic backgrounds will provide an opportunity in future studies to identify modifier genes that contribute to NPC1 ${ }^{\mathrm{I} 1061 \mathrm{~T}}$ protein stabilization.

The Npc1 $1^{I 1061 T}$ knock-in mouse presents a unique tool to assess candidate proteostatic therapies in vivo. Whereas the $\mathrm{NpCl}^{-1-}$ mouse model continues to be a valuable reagent in understanding and treating NPC disease, it is not amenable to testing therapies aimed at modulation of expression and/or post- 
translational protein processing. Our novel $\mathrm{Np} \mathrm{I}^{11061 \mathrm{~T}}$ mouse model not only overcomes this limitation, but also harbors the most common disease-causing mutation in human NPC1 disease. We show that in MEFs derived from the knock-in mice, SAHA treatment rescues the cholesterol trafficking phenotype, similar to results reported in human NPC $1^{\text {I1061T }}$ fibroblasts (Kim et al., 2007; Munkacsi et al., 2011; Pipalia et al., 2011). Together with the biochemical and immunofluorescence analysis of the $\mathrm{NPC} 1^{\mathrm{I} 1061 \mathrm{~T}}$ protein in the mouse tissues, these data indicate that the cellular behavior of the mutant protein closely models that of the most common disease-causing mutation in the human NPC1 locus (Gelsthorpe et al., 2008) and provide proof of concept that the mouse model will respond similarly to interventions that stabilize the human NPC1 ${ }^{11061 \mathrm{~T}}$ protein. Moreover, as the NPC1 mutation spectrum is dominated by single amino acid substitutions, this model may also provide general insights into pathogenic mechanisms evolving from impaired NPC1 protein stability caused by mutations other than I1061T.

\section{References}

Abi-Mosleh L, Infante RE, Radhakrishnan A, Goldstein JL, Brown MS (2009) Cyclodextrin overcomes deficient lysosome-to-endoplasmic reticulum transport of cholesterol in Niemann-Pick Type C cells. Proc Natl Acad Sci U S A 106:19316-19321. CrossRef Medline

Baudry M, Yao Y, Simmons D, Liu J, Bi X (2003) Postnatal development of inflammation in a murine model of Niemann-Pick Type C disease: immunohistochemical observations of microglia and astroglia. Exp Neurol 184:887-903. CrossRef Medline

Carstea ED, Morris JA, Coleman KG, Loftus SK, Zhang D, Cummings C, Gu J, Rosenfeld MA, Pavan WJ, Krizman DB, Nagle J, Polymeropoulos MH, Sturley SL, Ioannou YA, Higgins ME, Comly M, Cooney A, Brown A, Kaneski CR, Blanchette-Mackie EJ, et al. (1997) Niemann-Pick C1 disease gene: homology to mediators of cholesterol homeostasis. Science 277:228-231. CrossRef Medline

Chen Z, Fitzgerald RL, Averna MR, Schonfeld G (2000) A targeted apolipoprotein B-38.9-producing mutation causes fatty livers in mice due to the reduced ability of apolipoprotein B-38.9 to transport triglycerides. J Biol Chem 275:32807-32815. CrossRef Medline

Cianciola NL, Greene DJ, Morton RE, Carlin CR (2013) Adenovirus RIDalpha uncovers a novel pathway requiring ORP1L for lipid droplet formation independent of NPC1. Mol Biol Cell 24:3309-3325. CrossRef Medline

Collins K, Haupt E, Darrah M, Symula D (2006) Genetic modifiers of NPC2 deficiency in mice. In: Scientific conference on Niemann-Pick Type C disease. Tucson, AZ: Ara Parseghian Medical Research Foundation.

Cologna SM, Cluzeau CV, Yanjanin NM, Blank PS, Dail MK, Siebel S, Toth CL, Wassif CA, Lieberman AP, Porter FD (2014) Human and mouse neuroinflammation markers in Niemann-Pick disease, Type C1. J Inherit Metab Dis 37:83-92. CrossRef Medline

Davidson CD, Ali NF, Micsenyi MC, Stephney G, Renault S, Dobrenis K, Ory DS, Vanier MT, Walkley SU (2009) Chronic cyclodextrin treatment of murine Niemann-Pick C disease ameliorates neuronal cholesterol and glycosphingolipid storage and disease progression. PLoS One 4:e6951. CrossRef Medline

Davies JP, Ioannou YA (2000) Topological analysis of Niemann-Pick C1 protein reveals that the membrane orientation of the putative sterolsensing domain is identical to those of 3-hydroxy-3-methylglutaryl-CoA reductase and sterol regulatory element binding protein cleavageactivating protein. J Biol Chem 275:24367-24374. CrossRef Medline

Dietschy JM, Turley SD (2004) Thematic review series: brain lipids. Cholesterol metabolism in the central nervous system during early development and in the mature animal. J Lipid Res 45:1375-1397. CrossRef Medline

Fan M, Sidhu R, Fujiwara H, Tortelli B, Zhang J, Davidson C, Walkley SU, Bagel JH, Vite C, Yanjanin NM, Porter FD, Schaffer JE, Ory DS (2013) Identification of Niemann-Pick C1 disease biomarkers through sphingolipid profiling. J Lipid Res 54:2800-2814. CrossRef Medline

Gelsthorpe ME, Baumann N, Millard E, Gale SE, Langmade SJ, Schaffer JE, Ory DS (2008) Niemann-Pick Type C1 I1061T mutant encodes a functional protein that is selected for endoplasmic reticulum-associated deg- radation due to protein misfolding. J Biol Chem 283:8229-8236. CrossRef Medline

Goldin E, Roff CF, Miller SP, Rodriguez-Lafrasse C, Vanier MT, Brady RO, Pentchev PG (1992) Type C Niemann-Pick disease: a murine model of the lysosomal cholesterol lipidosis accumulates sphingosine and sphinganine in liver. Biochim Biophys Acta 1127:303-311. CrossRef Medline

Gondré-Lewis MC, McGlynn R, Walkley SU (2003) Cholesterol accumulation in NPC1-deficient neurons is ganglioside dependent. Curr Biol 13: 1324-1329. CrossRef Medline

Higashi Y, Murayama S, Pentchev PG, Suzuki K (1993) Cerebellar degeneration in the Niemann-Pick Type C mouse. Acta Neuropathol 85:175-184. Medline

Hùlková H, Ledvinová J, Asfaw B, Koubek K, Kopriva K, Elleder M (2005) Lactosylceramide in lysosomal storage disorders: a comparative immunohistochemical and biochemical study. Virchows Arch 447:31-44. CrossRef Medline

Infante RE, Wang ML, Radhakrishnan A, Kwon HJ, Brown MS, Goldstein JL (2008) NPC2 facilitates bidirectional transfer of cholesterol between NPC1 and lipid bilayers, a step in cholesterol egress from lysosomes. Proc Natl Acad Sci U S A 105:15287-15292. CrossRef Medline

Jiang X, Sidhu R, Porter FD, Yanjanin NM, Speak AO, te Vruchte DT, Platt FM, Fujiwara H, Scherrer DE, Zhang J, Dietzen DJ, Schaffer JE, Ory DS (2011) A sensitive and specific LC-MS/MS method for rapid diagnosis of Niemann-Pick C1 disease from human plasma. J Lipid Res 52:1435-1445. CrossRef Medline

Kim SJ, Lee BH, Lee YS, Kang KS (2007) Defective cholesterol traffic and neuronal differentiation in neural stem cells of Niemann-Pick Type C disease improved by valproic acid, a histone deacetylase inhibitor. Biochem Biophys Res Commun 360:593-599. CrossRef Medline

Kwon HJ, Abi-Mosleh L, Wang ML, Deisenhofer J, Goldstein JL, Brown MS, Infante RE (2009) Structure of N-terminal domain of NPC1 reveals distinct subdomains for binding and transfer of cholesterol. Cell 137:12131224. CrossRef Medline

Langmade SJ, Gale SE, Frolov A, Mohri I, Suzuki K, Mellon SH, Walkley SU, Covey DF, Schaffer JE, Ory DS (2006) Pregnane X receptor (PXR) activation: a mechanism for neuroprotection in a mouse model of NiemannPick C disease. Proc Natl Acad Sci U S A 103:13807-13812. CrossRef Medline

Lee EC, Yu D, Martinez de Velasco J, Tessarollo L, Swing DA, Court DL, Jenkins NA, Copeland NG (2001) A highly efficient Escherichia colibased chromosome engineering system adapted for recombinogenic targeting and subcloning of BAC DNA. Genomics 73:56-65. CrossRef Medline

Lee H, Lee JK, Bae YC, Yang SH, Okino N, Schuchman EH, Yamashita T, Bae JS, Jin HK (2014) Inhibition of GM3 synthase attenuates neuropathology of Niemann-Pick disease Type C by affecting sphingolipid metabolism. Mol Cells 37:161-171. CrossRef Medline

Li H, Repa JJ, Valasek MA, Beltroy EP, Turley SD, German DC, Dietschy JM (2005) Molecular, anatomical, and biochemical events associated with neurodegeneration in mice with Niemann-Pick Type C disease. J Neuropathol Exp Neurol 64:323-333. Medline

Liu B, Ramirez CM, Miller AM, Repa JJ, Turley SD, Dietschy JM (2010) Cyclodextrin overcomes the transport defect in nearly every organ of NPC1 mice leading to excretion of sequestered cholesterol as bile acid. J Lipid Res 51:933-944. CrossRef Medline

Loftus SK, Morris JA, Carstea ED, Gu JZ, Cummings C, Brown A, Ellison J, Ohno K, Rosenfeld MA, Tagle DA, Pentchev PG, Pavan WJ (1997) Murine model of Niemann-Pick C disease: mutation in a cholesterol homeostasis gene. Science 277:232-235. CrossRef Medline

Lopez ME, Klein AD, Hong J, Dimbil UJ, Scott MP (2012) Neuronal and epithelial cell rescue resolves chronic systemic inflammation in the lipid storage disorder Niemann-Pick C. Hum Mol Genet 21:2946-2960. CrossRef Medline

Maue RA, Burgess RW, Wang B, Wooley CM, Seburn KL, Vanier MT, Rogers MA, Chang CC, Chang TY, Harris BT, Graber DJ, Penatti CA, Porter DM, Szwergold BS, Henderson LP, Totenhagen JW, Trouard TP, Borbon IA, Erickson RP (2012) A novel mouse model of Niemann-Pick Type C disease carrying a D1005G-Npc1 mutation comparable to commonly observed human mutations. Hum Mol Genet 21:730-750. CrossRef Medline

McGlynn R, Dobrenis K, Walkley SU (2004) Differential subcellular localization of cholesterol, gangliosides, and glycosaminoglycans in murine 
models of mucopolysaccharide storage disorders. J Comp Neurol 480: 415-426. CrossRef Medline

Millard EE, Srivastava K, Traub LM, Schaffer JE, Ory DS (2000) NiemannPick Type C1 (NPC1) overexpression alters cellular cholesterol homeostasis. J Biol Chem 275:38445-38451. CrossRef Medline

Millard EE, Gale SE, Dudley N, Zhang J, Schaffer JE, Ory DS (2005) The sterol-sensing domain of the Niemann-Pick C1 (NPC1) protein regulates trafficking of low density lipoprotein cholesterol. J Biol Chem 280:2858128590. CrossRef Medline

Millat G, Marçais C, Rafi MA, Yamamoto T, Morris JA, Pentchev PG, Ohno K, Wenger DA, Vanier MT (1999) Niemann-Pick C1 disease: the I1061T substitution is a frequent mutant allele in patients of Western European descent and correlates with a classic juvenile phenotype. Am J Hum Genet 65:1321-1329. CrossRef Medline

Morris MD, Bhuvaneswaran C, Shio H, Fowler S (1982) Lysosome lipid storage disorder in NCTR-BALB/c mice. I. Description of the disease and genetics. Am J Pathol 108:140-149.

Munkacsi AB, Chen FW, Brinkman MA, Higaki K, GutiérrezGD, Chaudhari J, Layer JV, Tong A, Bard M, Boone C, Ioannou YA, Sturley SL (2011) An "exacerbate-reverse" strategy in yeast identifies histone deacetylase inhibition as a correction for cholesterol and sphingolipid transport defects in human Niemann-Pick Type C disease. J Biol Chem 286:2384223851. CrossRef Medline

Neufeld EB, Wastney M, Patel S, Suresh S, Cooney AM, Dwyer NK, Roff CF, Ohno K, Morris JA, Carstea ED, Incardona JP, Strauss JF 3rd, Vanier MT, Patterson MC, Brady RO, Pentchev PG, Blanchette-Mackie EJ (1999) The Niemann-Pick $\mathrm{C} 1$ protein resides in a vesicular compartment linked to retrograde transport of multiple lysosomal cargo. J Biol Chem 274: 9627-9635. CrossRef Medline

Newberry EP, Xie Y, Kennedy S, Han X, Buhman KK, Luo J, Gross RW, Davidson NO (2003) Decreased hepatic triglyceride accumulation and altered fatty acid uptake in mice with deletion of the liver fatty acidbinding protein gene. J Biol Chem 278:51664-51672. CrossRef Medline

Ory DS (2000) Niemann-Pick Type C: a disorder of cellular cholesterol trafficking. Biochim Biophys Acta 1529:331-339. CrossRef Medline

Park WD, O'Brien JF, Lundquist PA, Kraft DL, Vockley CW, Karnes PS, Patterson MC, Snow K (2003) Identification of 58 novel mutations in Niemann-Pick disease Type C: correlation with biochemical phenotype and importance of PTC1-like domains in NPC1. Hum Mutat 22:313-325. CrossRef Medline

Pentchev PG, Gal AE, Booth AD, Omodeo-Sale F, Fouks J, Neumeyer BA, Quirk JM, Dawson G, Brady RO (1980) A lysosomal storage disorder in mice characterized by a dual deficiency of sphingomyelinase and glucocerebrosidase. Biochim Biophys Acta 619:669-679. CrossRef Medline

Pentchev PG, Boothe AD, Kruth HS, Weintroub H, Stivers J, Brady RO (1984) A genetic storage disorder in BALB/C mice with a metabolic block in esterification of exogenous cholesterol. J Biol Chem 259:5784-5791. Medline

Pipalia NH, Cosner CC, Huang A, Chatterjee A, Bourbon P, Farley N, Helquist P, Wiest O, Maxfield FR (2011) Histone deacetylase inhibitor treatment dramatically reduces cholesterol accumulation in NiemannPick Type C1 mutant human fibroblasts. Proc Natl Acad Sci U S A 108: 5620-5625. CrossRef Medline

Porter FD, Scherrer DE, Lanier MH, Langmade SJ, Molugu V, Gale SE, Olzeski D, Sidhu R, Dietzen DJ, Fu R, Wassif CA, Yanjanin NM, Marso SP, House J, Vite C, Schaffer JE, Ory DS (2010) Cholesterol oxidation products are sensitive and specific blood-based biomarkers for Niemann-Pick $\mathrm{C} 1$ disease. Sci Transl Med 2:56ra81. CrossRef Medline

Pressey SN, Smith DA, Wong AM, Platt FM, Cooper JD (2012) Early glial activation, synaptic changes and axonal pathology in the thalamocortical system of Niemann-Pick Type C1 mice. Neurobiol Dis 45:1086-1100. CrossRef Medline
Reid PC, Sakashita N, Sugii S, Ohno-Iwashita Y, Shimada Y, Hickey WF, Chang TY (2004) A novel cholesterol stain reveals early neuronal cholesterol accumulation in the Niemann-Pick Type C1 mouse brain. J Lipid Res 45:582-591. CrossRef Medline

Shio H, Fowler S, Bhuvaneswaran C, Morris MD (1982) Lysosome lipid storage disorder in NCTR-BALB/c mice. II. Morphologic and cytochemical studies. Am J of Pathol 108:150-159.

Sillitoe RV, Joyner AL (2007) Morphology, molecular codes, and circuitry produce the three-dimensional complexity of the cerebellum. Ann Rev Cell Dev Biol 23:549-577. CrossRef Medline

Silverman J, Stone DW, Powers JD (1992) The lipid composition of milk from mice fed high or low fat diets. Lab Anim 26:127-131. CrossRef Medline

Smith D, Wallom KL, Williams IM, Jeyakumar M, Platt FM (2009) Beneficial effects of anti-inflammatory therapy in a mouse model of NiemannPick disease Type C1. Neurobiol Dis 36:242-251. CrossRef Medline

Stein VM, Crooks A, Ding W, Prociuk M, O’Donnell P, Bryan C, Sikora T, Dingemanse J, Vanier MT, Walkley SU, Vite CH (2012) Miglustat improves Purkinje cell survival and alters microglial phenotype in feline Niemann-Pick disease Type C. J Neuropathol Exp Neurol 71:434-448. CrossRef Medline

Vanier MT (1983) Biochemical studies in Niemann-Pick disease. I. Major sphingolipids of liver and spleen. Biochim Biophys Acta 750:178-184. CrossRef Medline

Vanier MT (1999) Lipid changes in Niemann-Pick disease Type C brain: personal experience and review of the literature. Neurochem Res 24:481489. CrossRef Medline

Vanier MT (2010) Niemann-Pick disease Type C. Orphanet J Rare Dis 5:16. CrossRef Medline

Walkley SU, Suzuki K (2004) Consequences of NPC1 and NPC2 loss of function in mammalian neurons. Biochim Biophys Acta 1685:48-62. CrossRef Medline

Warming S, Costantino N, Court DL, Jenkins NA, Copeland NG (2005) Simple and highly efficient BAC recombineering using galK selection. Nucleic Acids Res 33:e36. CrossRef Medline

Wojtanik KM, Liscum L (2003) The transport of low density lipoproteinderived cholesterol to the plasma membrane is defective in NPC1 cells. J Biol Chem 278:14850-14856. CrossRef Medline

Xie X, Brown MS, Shelton JM, Richardson JA, Goldstein JL, Liang G (2011) Amino acid substitution in NPC1 that abolishes cholesterol binding reproduces phenotype of complete NPC1 deficiency in mice. Proc Natl Acad Sci U S A 108:15330-15335. CrossRef Medline

Yang C, Rahimpour S, Lu J, Pacak K, Ikejiri B, Brady RO, Zhuang Z (2013) Histone deacetylase inhibitors increase glucocerebrosidase activity in Gaucher disease by modulation of molecular chaperones. Proc Natl Acad Sci U S A 110:966-971. CrossRef Medline

Zampieri S, Mellon SH, Butters TD, Nevyjel M, Covey DF, Bembi B, Dardis A (2009) Oxidative stress in NPC1 deficient cells: protective effect of allopregnanolone. J Cell Mol Med 13:3786-3796. CrossRef Medline

Zervas M, Somers KL, Thrall MA, Walkley SU (2001) Critical role for glycosphingolipids in Niemann-Pick disease Type C. Curr Biol 11:12831287. CrossRef Medline

Zhang JR, Coleman T, Langmade SJ, Scherrer DE, Lane L, Lanier MH, Feng C, Sands MS, Schaffer JE, Semenkovich CF, Ory DS (2008) Niemann-Pick $\mathrm{C} 1$ protects against atherosclerosis in mice via regulation of macrophage intracellular cholesterol trafficking. J Clin Invest 118:2281-2290. CrossRef Medline

Zhou S, Davidson C, McGlynn R, Stephney G, Dobrenis K, Vanier MT, Walkley SU (2011) Endosomal/lysosomal processing of gangliosides affects neuronal cholesterol sequestration in Niemann-Pick disease Type C. Am J Pathol 179:890-902. CrossRef Medline 